(2) norden 



\section{Evaluering av Småsamfundsgruppens arbete}

En nordisk workshop i Hafnarfjordur 25-26 oktober 2007

TemaNord 2008:514 
Evaluering av Småsamfundsgruppens arbete

En nordisk workshop i Hafnarfjordur 25-26 oktober 2007

TemaNord 2008:514

(C) Nordic Council of Ministers, Copenhagen 2007

ISBN 978-92-893-1656-9

Print: Ekspressen Tryk \& Kopicenter

Copies: 0

Printed on environmentally friendly paper

This publication can be ordered on www.norden.org/order. Other Nordic publications are available at www.norden.org/publications

Printed in Denmark

Nordic Council of Ministers

Store Strandstræde 18

DK-1255 Copenhagen K

Phone (+45) 33960200

Fax (+45) 33960202

www.norden.org
Nordic Council

Store Strandstræde 18

DK-1255 Copenhagen K

Phone (+45) 33960400

Fax (+45) 33111870

\section{Nordic co-operation}

Nordic cooperation is one of the world's most extensive forms of regional collaboration, involving Denmark, Finland, Iceland, Norway, Sweden, and three autonomous areas: the Faroe Islands, Greenland, and Åland.

Nordic cooperation has firm traditions in politics, the economy, and culture. It plays an important rol in European and international collaboration, and aims at creating a strong Nordic community in a strong Europe.

Nordic cooperation seeks to safeguard Nordic and regional interests and principles in the global community. Common Nordic values help the region solidify its position as one of the world's most innovative and competitive. 


\section{Innehåll}

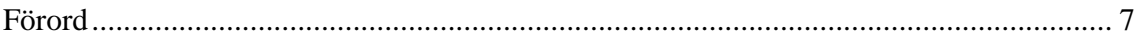

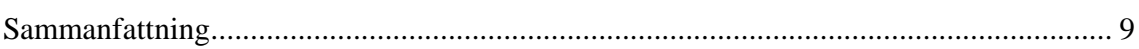

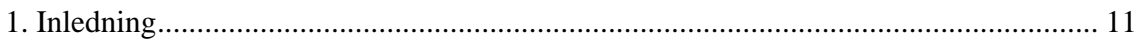

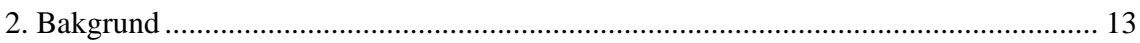

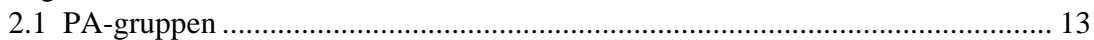

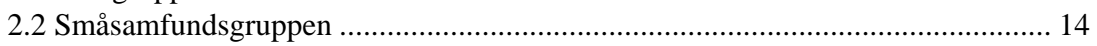

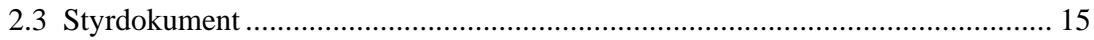

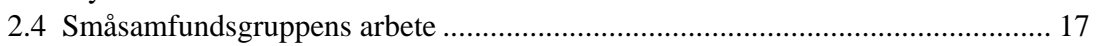

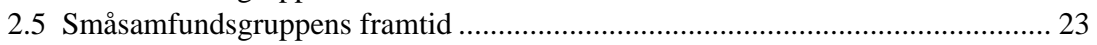

3. Workshop i Hafnarfjörður 25-26 oktober 2007........................................................... 25

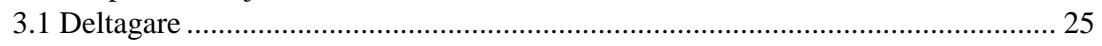

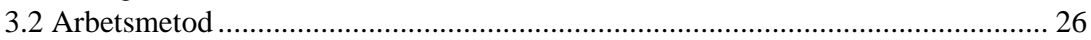

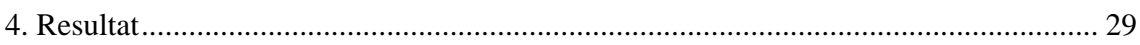

4.1 Har Småsamfundsgruppens arbete varit framgångsrikt? Vad har lyckats

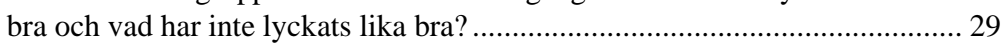

4.2 Finns det ett behov för gruppen i det framtida nordiska samarbetet? .................. 31

4.3 I så fall, vilka skulle så vara gruppens fokusområden/ huvuduppgifter? .............. 31

4.4 Kan gruppens resultat få en bättre användning/spridning - på hemmaplan eller bland övriga aktörer/länder - direkt eller genom översättningar? ............ 33

4.5 Borde samarbetet utvidgas för att täcka en större del av Norden? ......................... 34

4.6 Finns det ett potential för samarbete med små- eller ösamfund utanför Norden?. 34

4.7 Hur kan småsamfundens intresser och utmaningar bäst ivaretas i en reviderad Nordisk strategi för hållbar utveckling, samt i ett nytt Nordiskt Miljöhandlingsprogram vilka planeras gälla för perioden 2009-2012? .................... 35

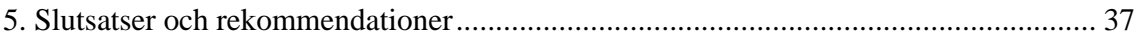

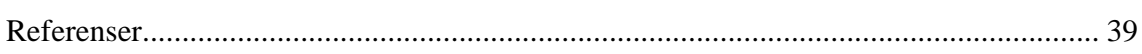

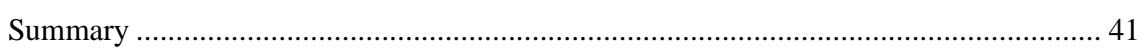

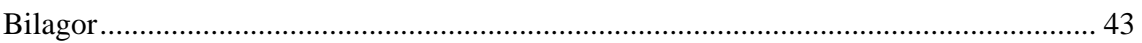

Bilaga 1. Småsamfundsgruppens mandat ................................................................ 43

Syfte

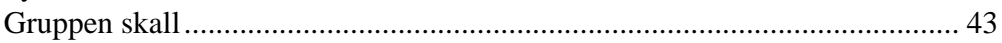

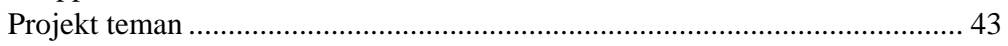

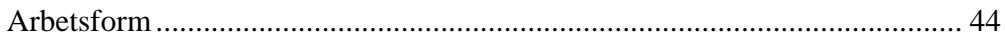

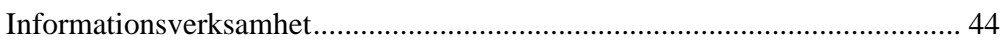

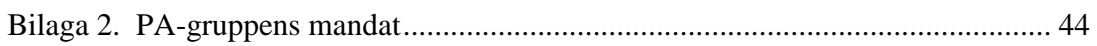





\section{Förord}

Småsamfundsgruppen är den grupp i Nordiska Ministerrådets regi som arbetar med miljö- och hållbarhetsfrågor med en särskild relevans för småsamfund i Norden. Gruppens mandat utlöper i slutet av år 2008. För att skapa en bas för beslut om gruppens arbete efter 2008 har gruppen gjort en bedömning av sitt arbete hittills. Samtidigt vill gruppen bidra till revidering av Det Nordiska Miljöhandlingsprogrammet och Den Nordiska strategin för hållbar utveckling (BU-strategin). Den viktigaste delen av bedömningen var en intern workshop som hölls i Hafnarfjordur på Island den 25-26 oktober 2007 med deltagare från de nordiska områden som varit mest aktiva i gruppens arbete. Detta dokument innehåller ett underlag för denna workshop, samt en sammanfattning av workshopens resultat.

Borgarnes, december 2007

Stefán Gíslason

Environice, Island 



\section{Sammanfattning}

Småsamfundsgruppen är den grupp i Nordiska Ministerrådets regi som arbetar med miljö- och hållbarhetsfrågor med en särskild relevans för småsamfund i Norden. Gruppens mandat utlöper i slutet av år 2008. För att skapa en bas för beslut om gruppens arbete efter 2008 har gruppen gjort en bedömning av sitt arbete hittills. Samtidigt vill gruppen bidra till revidering av Det Nordiska Miljöhandlingsprogrammet och Den Nordiska strategin för hållbar utveckling (BU-strategin). Den viktigaste delen av bedömningen var en intern workshop som hölls i Hafnarfjordur på Island den 25-26 oktober 2007 med deltagare från de nordiska områden som varit mest aktiva i gruppens arbete, d.v.s. Island, Färöarna, Åland och Nord-Norge. Vidare var Nordkalottrådet representerat.

Workshopens primära mål var att hitta svar på sju olika frågor som framlades i ett underlagsdokument och som fokuserade på Småsamfundsgruppens framgång hittills samt på behovet för gruppen framöver, och i så fall vilka områden som borde prioriteras.

Enligt workshopens resultat har Småsamfundsgruppens arbete största dels varit framgångsrikt. Detta gäller särskilt arbetet med Lokal Agenda 21 och avfallsfrågor. Den största framgången anses dock ligga i gruppens funktion som en plattform för utväxling av idéer och erfarenheter mellan de deltagande områdena. Det som inte tycks ha lyckats lika bra är spridningen av det "goda budskapet”, såsom till lokalförvaltningar, branschorganisationer och enskilda företag.

Det finns utan tvekan ett behov för Småsamfundsgruppen i det framtida nordiska samarbetet. Det kommer nämligen alltid att finnas speciella uppgifter som inte kan lösas på samma sätt i småsamfund som i de stora samhällena. För att kunna sköta sina uppgifter behöver gruppen tillräcklig flexibilitet för att kunna löpande ta tag i aktuella uppdrag.

Lokal Agenda 21, avfallsfrågor i småsamfund samt klimataspekter identifieras som några av Småsamfundsgruppens viktigaste uppgifter under de kommande åren. Det föreslås att gruppen löpande granskar de aktiviteter som övriga grupper under Nordiska Ministerrådets miljösektor har på gång samt identifierar vilka av dessa som behöver särskild tillpassning till småsamfund. Vidare föreslås det att gruppen tar fram en utvärdering av de mest aktuella problemställningarna och sedan utarbetar en ny problembeskrivning.

Informationsspridning identifierades som Småsamfundsgruppens största svaghet. Gruppens hemsida borde fungera bättre som en upplysningstavla för gruppens olika projekt och aktiviteter. Gruppens medlemmar bör också ta på sig en större roll som "informationsspridningsagenter” på nationell nivå, bl.a. genom att informera om gruppens arbete i 
föredrag och annan kommunikation inför sina respektive forum. För att komma längre i detta kunde Småsamfundsgruppen även organisera möten med representanter från kommuner för att skapa en översikt över aktuella problemställningar i småsamfunden samt för att sprida information om gruppens arbete.

Generellt skulle översättningar bidra till bättre användning eller spridning av Småsamfundsgruppens resultat. I många fall kunde man få mer för pengarna genom att bevilja medel till översättningar i stället för till tryckning av rapporter.

Eftersom småsamfund faktiskt utgör den geografiska huvuddelen av Nordens territorium är det särskilt viktigt att småsamfundens intressen och utmaningar avspeglas i Nordiska Ministerrådets strategier och handlingsprogram, samt i implementeringen av dessa. I samband med detta bör Småsamfundsgruppens medlemmar informera sina respektive miljöministrar om gruppens arbete.

Småsamfundsgruppen borde ta fram ett policydokument för att identifiera vilka aspekter som är viktiga i småsamfundssammanhang. Ett sådant dokument kunde vara ett nyttigt inspel till revideringen av den Nordiska strategin för hållbar utveckling, samt av Miljöhandlingsprogrammet. 


\section{Inledning}

För att skapa en bas för beslut om Småsamfundsgruppens fortsatta arbete, samt för att bidra till revidering av Det Nordiska Miljöhandlingsprogrammet och Den Nordiska strategin för hållbar utveckling (BUstrategin), fick gruppen under våren 2007 medel från PA-gruppen för att genomföra ett projekt omkring bedömning av gruppens arbete hittills. Konsultfirman Environice på Island hyrdes in för att sköta uppgiften. Projektets resultat skulle bl.a. innehålla svar på följande frågor:

1. Har Småsamfundsgruppens arbete varit framgångsrikt? Vad har lyckats bra och vad har inte lyckats lika bra?

2. Finns det behov för gruppen i det framtida nordiska samarbetet?

3. I så fall, vilka skulle då vara gruppens fokusområden/huvuduppgifter?

4. Borde samarbetet utvidgas för att täcka en större del av Norden?

5. Finns det potential för samarbete med små- eller ösamfund utanför Norden?

6. Hur kan småsamfundens intressen och utmaningar bäst tillvaratas i en reviderad Nordisk strategi för hållbar utveckling, vilken planeras gälla för perioden 2009-2012?

Som ett första steg i projektet togs det fram ett underlagsdokument med en översikt över Småsamfundsgruppens aktiviteter t.o.m. år 2007. Detta dokument användes sedan som ett underlag för diskussioner i en intern workshop i Hafnarfjordur på Island den 25-26 oktober 2007. Enligt projektplanen definierades denna workshop som projektets viktigaste del. Deltagare i workshopen kom från Island, Färöarna, Åland och NordNorge, d.v.s. från de områden som varit mest aktiva i Småsamfundsgruppens arbete. Deltagare från Grönland inbjöds också, men hade inte möjlighet att delta. Vidare inbjuds Nordkalottrådet att skicka en representant till workshopen. Workshopens primära mål var att hitta svar på ovanstående frågor, vilket främst gjordes genom arbete i mindre grupper.

Efter workshopen togs det fram en sammanställning av workshopens resultat och rekommendationer. De primära målgrupperna för detta är Småsamfundsgruppen, PA-gruppen, ÄK-M och de som arbetar med revidering av den Nordiska strategin för hållbar utveckling (BU-strategin).

Denna rapport består av tre delar, d.v.s. det ursprungliga underlagsdokumentet, berättelse om själva workshopen, samt den ovannämnda sammanställningen av workshopens resultat och rekommendationer. 



\section{Bakgrund}

Nordiska ministerrådet (NMR) bildades 1971 och är de nordiska regeringarnas samarbetsorgan. Trots namnet består rådet inte bara av ett utan 11 olika ministerråd, härunder tio fackministerråd samt samarbetsministerrådet (MR-SAM). Ett av de tio fackministerråden är Nordiska Ministerrådet för miljöfrågor (MR-M).

Ämbetsmannakommittén för miljöfrågor (ÄK-M) förbereder MR-M:s arbete och genomför de uppgifter som ministerrådets beslut medför. Ämbetsmannakommitténs arbetsutskott (AU) planerar och samordnar arbetet vilket bl.a. innebär att följa och koordinera de olika arbetsgruppernas arbete.

Under ÄK-M finns det ett antal fasta arbetsgrupper, härunder fem grupper som tillhör ÄK-M direkt samt sex tvärsektoriella grupper som också jobbar för övriga sektorer/ämbetsmannakommittéer inom Nordiska Ministerrådet. Arbetsgrupperna arbetar efter godkända verksamhetsplaner och har egna rambudgetar som beviljas för olika projekt och aktiviteter inför gruppens ansvarsområden. Grupperna spelar således en central roll i det miljöpolitiska samarbetet i Norden.

\subsection{PA-gruppen}

PA-gruppen (Produkt och avfall) är en av fem permanenta arbetsgrupper som ligger direkt under ÄK-M. Enligt gruppens mandat (jfr. bilaga 2) skall den

"fremme en udvikling som bygger på bæredygtig produktion og konsumption. Hertil kommer nordiske indspil til forebyggelse af mængden og miljøfarligheden af affald, øget genanvendelse af affald, bedre miljøkundskab i befolkningen og i virksomhederne, bedre produktinformation samt fremme af grønne markeder og bæredygtig og renere teknologi”. Gruppen skall också ta "udgangspunkt i relevante mål i den nordiske strategi for bæredygtig udvikling 2005-2008, særligt under område 2: Bæredygtige produktions- og forbrugsmønstre og område 15: Allmänhetens deltagande och lokala Agenda 21”.

PA-gruppen ${ }^{1}$ etablerades ursprungligen i det sista århundradets nionde årtionde. I 1987 hade gruppen namnet "Arbetsgrupp för avfall och återvinning”, men omnämndes kort efter det till "Renare Teknologi, Avfallsoch Återvinningsgruppen" (RTGA-gruppen) och sedan till "Renare Teknologigruppen” (RT-gruppen). Sedan början av 1999 pratas det om

\footnotetext{
${ }^{1}$ PA-gruppens hemsida: http://www.norden.org/miljoe/pa/sk
} 
PA-gruppen (Produkt- och avfallsgruppen). Ämbetsmanna-kommittén för miljöfrågor (ÄK-M) finansierar PA-gruppens arbete med årliga beviljanden. Under de sista åren har dessa i genomsnitt varit på ca 4 MDKK per år.

RTGA-gruppen förberedde ett "Nordiskt handlingsprogram om renere teknologi, affald og genanvendelse" ${ }^{\text {"2 }}$ som antogs av MR-M den 2:a mars 1990. Med detta handlingsprogram som underlag genomförde RTGAgruppen en workshop på Bornholm i 1991 för att "belyse de særlige problemer, affaldsbehandling frembyder for ø-samfund”. Som resultat av workshopen utpekades ett antal prioriterade områden som man borde arbeta vidare med, härunder bl.a. organisk avfall, återvinning, avfallshantering i samfunden, miljöfarligt avfall och deponering.

\subsection{Småsamfundsgruppen}

I koppling till workshopen i Bornholm 1991 tillsatte RTGA-gruppen en undergrupp, "Små- og øsamfundsgruppen”, för att "følge miljøforhold, herunder forhold vedrørende produkter og produktion samt affald af scerlig betydning for småsamfund i Norden og i Arktis”. Gruppen skulle med utgångspunkt i detta framlägga förslag till RTGA-gruppen "med hensyn til igangscettelse af f.eks. projekter inden for de områder, der scerligt knytter sig til småsamfund”.

Sedan 1991 har Småsamfundsgruppen ${ }^{3}$ alltså varit en av RT- eller PA-gruppens undergrupper. Enligt PA-gruppens nuvarande mandat (2005-2008) etablerar gruppen projektgrupper och kompetensnätverk för att "fremme formidling af information mellem nordiske eksperter og/eller myndigheder og for at understøtte gruppens virksomhed". Antal undergrupper varierar lite från tid till tid och reflekterar vilka uppgifter som står högst på agendan. I nuläget (oktober 2007) har PA-gruppen sju undergrupper samt tre "kompetensnätverk". Småsamfundsgruppens hemmaplan i Nordiska Ministerrådets organisationsdiagram utgår av bild 1. Gruppen söker PA-gruppen för finansiering av enskilda projekt och aktiviteter. Under de sista åren har gruppen i genomsnitt fått beviljat ett belopp på ca 400000 DKK per år, d.v.s. omkring en tiondedel av PA-gruppens totala budget.

\footnotetext{
2 Nordiska Ministerrådet. Nordic Action Programme on Cleaner Technologies, Waste and Recycling. Nordic Council of Ministers, NU 1990:004E, Copenhagen 1990.http://www.norden.org/pub/sk/showpub.asp?pubnr=1990:004E (Utsåld, inte nedladdningsbar)

${ }^{3}$ Småsamfundsgruppenshemsida: http://www.norden.org/miljoe/pa/sk/pa smaasamfundsgrupp.asp
} 


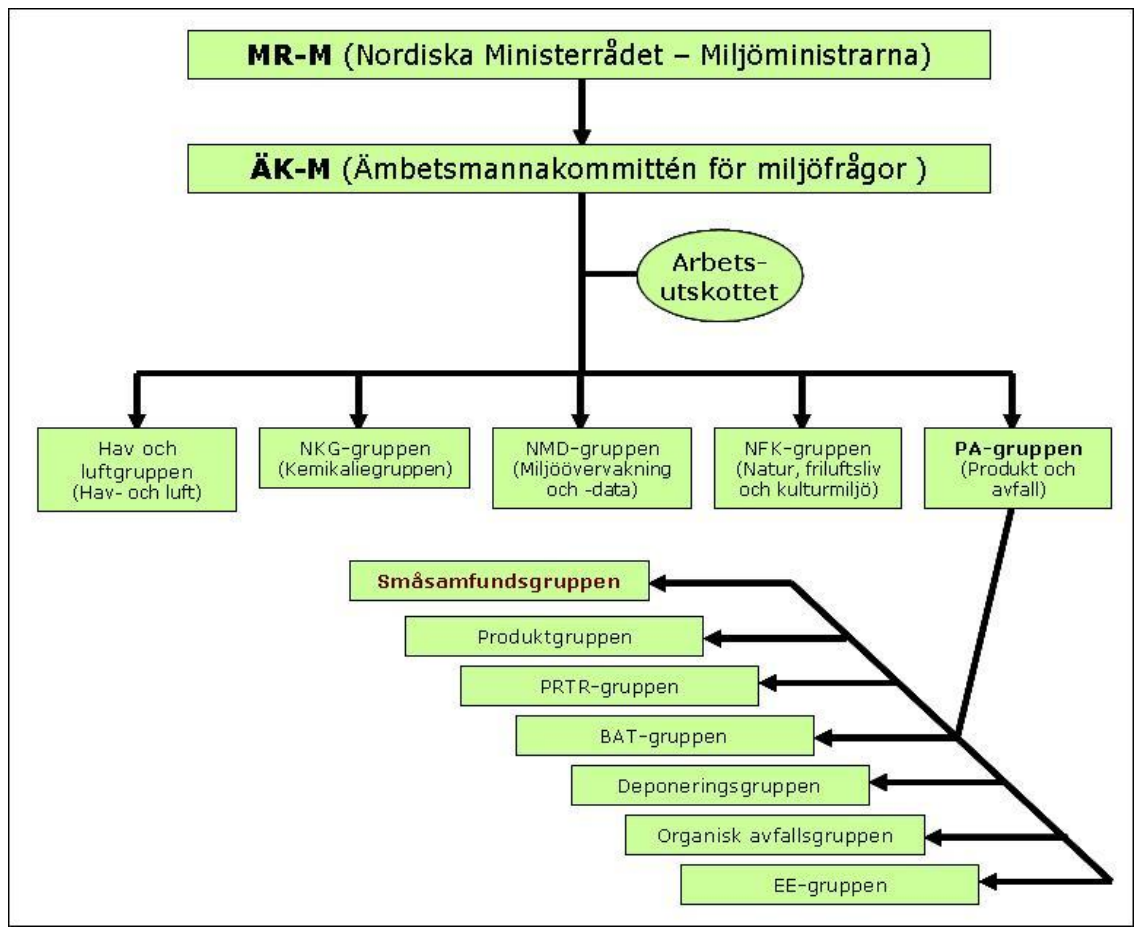

Bild 1. Småsamfundsgruppens plats i Nordiska Ministerrådets miljö-organisationsdiagram. (Tvärsektoriella arbetsgrupper under ÄK-M syns inte på diagrammet och heller inte ev. undergrupper under de övriga fyra permanenta arbetsgrupperna, utan endast under $P A)$.

I oktober 2007 hade Småsamfundsgruppen följande medlemmar:

- Sigurbjörg Sæmundsdóttir, Miljöministeriet Island, ordförande

- Jákup P. Joensen, Umhvørvisstovan, Färöarna

- Evy Jørgensen, Fylkesmannen i Finnmark, Norge

- Mona Kårebring-Olsson, Ålands Landskapsregering, Åland

Etableringen av Småsamfundsgruppen i sin tid var ett tecken eller ett bevis på att det behövdes en särskild insats på miljöområdet i småsamfund, för att miljöstandarden i Norden kunde vara av en harmoniserat hög karaktär. P.g.a. av den stora skillnaden som uppstår mellan isolerade småsamfund och storstäderna måste miljöutmaningar i småsamfund ofta mötas på något annat sätt än man generellt förutsätter och avspeglas i EU-direktiv och enskilda beslut på nationell eller internationell nivå. Därför fanns det ett behov för att se närmare på lokala miljöproblem i småsamfunden och ev. hitta mer skräddarsydda lösningar som kan genomföras i praktiken.

\subsection{Styrdokument}

Småsamfundsgruppens arbete bör ta utgångspunkt i olika styrdokument i Nordiska Ministerrådets regi. Gruppen har sitt eget mandat (jfr. bilaga 1) 
godkänt av PA-gruppen. Det nuvarande mandatet gäller för perioden 15 september 2005 till 31 december 2008, med möjlighet för en årlig revidering. PA-gruppen har också ett mandat (jfr. bilaga 2) som godkänts av ÄK-M och gäller t.o.m. slutet av år 2008. För att skapa en översikt över de punkter som PA-gruppen främst kommer att fokusera på tills slutet av mandatperioden har gruppen också tagit fram en 3-årig handlingsplan för 2006-2008. Ramen för PA-gruppens aktiviteter definieras i mer detalj senare i gruppens årliga arbetsprogram.

Det nordiska miljöhandlingsprogrammet (MHP) 2005-2008 är en bas för miljösamarbetet inom NMR. Den nordiska strategin för hållbar utveckling (BU-strategin) är det dokument som står överst i NMR:s dokumenthierarki och som tänks fungera som ett paraply för de olika sektorprogrammen inom Nordiska Ministerrådet, härunder miljöhandlingsprogrammet. BU-strategin ställer långsiktiga mål för hur Norden skall utvecklas fram till år 2020 och beskriver vilka mål och insatser man kommer att arbeta för under varje 4-årsperiod. Den nuvarande strategin gäller för perioden 2005-2008.

Kopplingen mellan de olika styrdokumenten som nämnts ovan kan beskrivas som utgår av bild 2 .

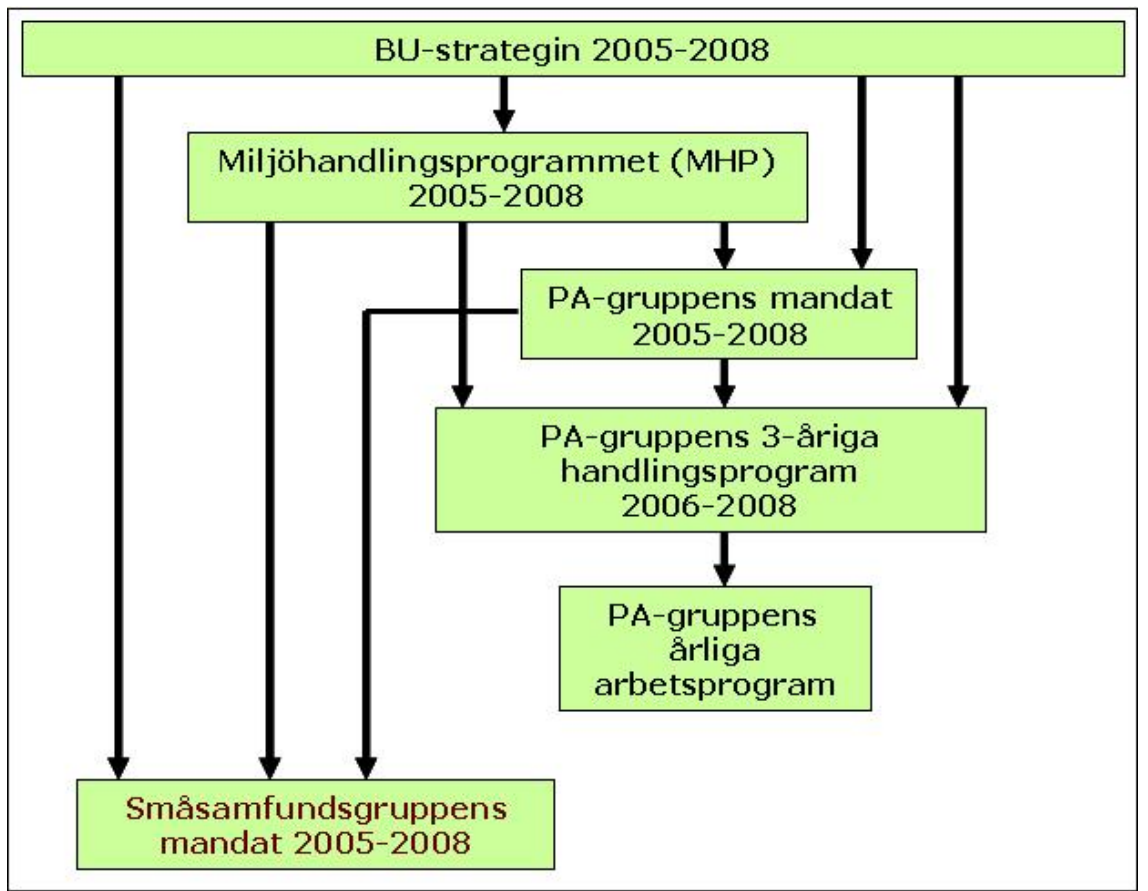

Bild 1. Kopplingen mellan Småsamfundsgruppens mandat och övriga aktuella styrdokument i Nordiska Ministerrådets regi.

I tillägg till de styrdokument som nämns ovan bör man i sitt arbete inom Nordiska Ministerrådet ta hänsyn till det gällande ordförandeskapsprogrammet. Ordförandeskapet i NMR är på ett år och roterar mellan länderna enligt en särskild ordning. Inför varje år presenteras ett ordförandeskapsprogram med de punkter som ordförandelandet vill priori- 
tera i det nordiska samarbetet på regeringsnivå under sitt ordförandeskap. Finland har ordförandeskapet i Nordiska Ministerrådet 2007. ${ }^{4}$

\subsection{Småsamfundsgruppens arbete}

Som framgår enligt ovan har Småsamfundsgruppen funnits sedan 1991, alltså i 16 år. Mitt i denna period, d.v.s. under sensommaren 1999 utgav gruppen en broschyr på danska och engelska med en översikt och en kort sammanfattning av de publikationer som gruppen utarbetade i samband med projekt och seminarier under perioden 1991-1999. ${ }^{5}$

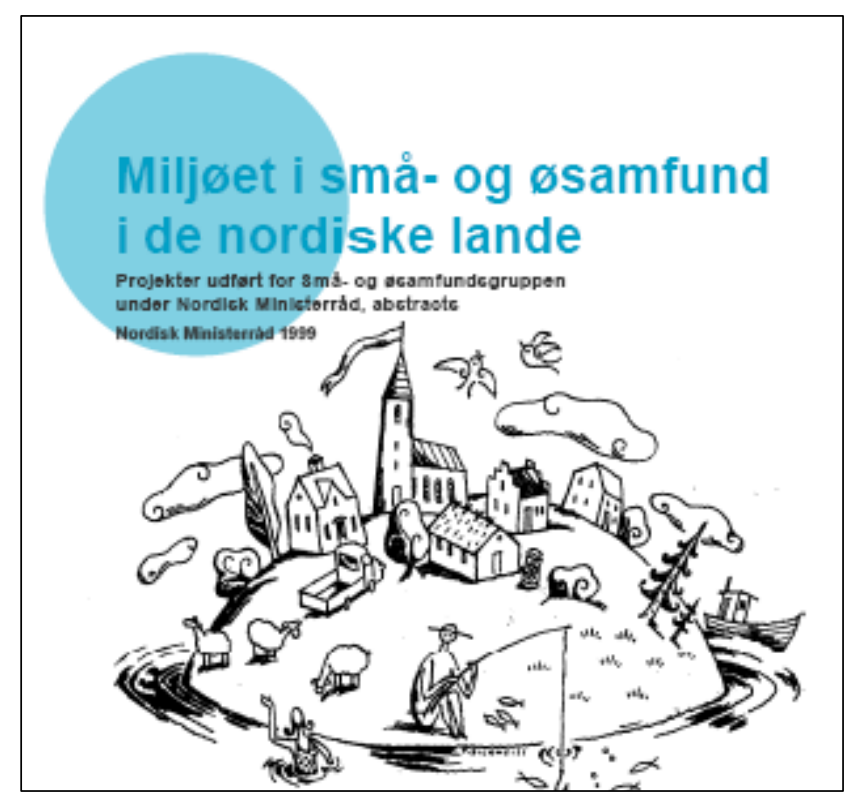

Bild 2. Framsidan till Småsamfundsgruppens broschyr 1999

Under perioden 1991-1999 var Småsamfundsgruppens fokus främst på avfallsfrågor, men också i viss mån på renare teknologi och miljöstyrning. Som framkommer i den nämnda broschyren genomförde gruppen totalt 14 projekt och tre seminarier under denna period. Av de 14 projekten handlade nio om avfall, fyra om miljöstyrning och renare teknologi och ett om miljöhandlingsplaner i små kommuner. Två av gruppens tre seminarier i perioden handlade om avfall som huvudtema.

\footnotetext{
${ }^{4}$ Nordiska Ministerrådet. Möjligheternas Norden - Nära dig. Finlands ordförandeskapsprogram för Nordiska Ministerrådet 2007. Nordiska Ministerrådet, ANP 2006:763, Köpenhamn 2006. http://www.norden.org/pub/sk/showpub.asp?pubnr=2006:763

${ }^{5}$ Nordiska Ministerrådet. Miljøet i små- og øsamfund i de nordiske lande. Projekter udført for Små- og øsamfundsgruppen under Nordisk Ministerråd, abstracts. Nordisk Ministerråd, København 1999. http://www.norden.org/pub/sk/showpub.asp?pubnr=2000:427 Nordiska Ministerrådet. The Environment in Small and Island Communities in the Nordic Countries. Projects commissioned by The group for small and island communities under the Nordic Council of Ministers, Abstracts. Nordic Council of Minister, Copenhagen 1999. http://www.norden.org/pub/sk/showpub.asp?pubnr=2000:428
} 
Som framkommer i broschyren var de avrapporterade projekten främst tänkt som en idé- och inspirationskälla för småsamfund generellt till lösning av hittillsvarande miljöproblem, men småsamfundsgruppen har också varit uppmärksam på att själva genomförandet av projekten kan bidra och har i många tillfällen bidragit till en ökat medvetenhet om miljöfrågor i de lokala samfunden. Det är alltså inte endast resultaten från projekten utan också själva projektprocessen som varit värdefull.

Tabell 1 ger en översikt över samtliga projekt och workshops genomförda av Småsamfundsgruppen under perioden 1991-1999. Tabell 2 ger en liknande översikt över aktiviteter under perioden 2000-2007. 
Tabell 1. Projekt och workshops genomförda av Småsamfundsgruppen i perioden 1991-1999. (P-projekt, WS-workshop/seminarium, CP-Renare Teknologi (Cleaner Production), EMS-Miljöstyrning (Environmental Management), LA21-Lokal Agenda 21).

\begin{tabular}{|c|c|c|c|c|c|c|}
\hline \multirow[b]{2}{*}{ Start } & \multirow[b]{2}{*}{ Slut } & \multirow[b]{2}{*}{ Titel och beskrivning } & \multicolumn{2}{|c|}{ Fokus } & \multirow[b]{2}{*}{ 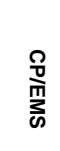 } & \multirow[b]{2}{*}{ 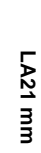 } \\
\hline & & & $\sum_{\omega}^{D}$ & 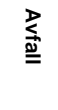 & & \\
\hline 1991 & 1991 & $\begin{array}{l}\text { Affaldsbehandling i nordiske øsamfund } \\
\text { Workshop på Bornholm } 1991 \\
\text { Kontrakt: Heilsufrøðiliga Starvsstovan, FO } \\
\text { Publikation: Kopierad résumérapport till deltagare och RT- } \\
\text { gruppen }\end{array}$ & WS & $x$ & & \\
\hline \multirow[t]{3}{*}{1993} & 1993 & $\begin{array}{l}\text { Organisk affald fra fiskeindustrien } \\
\text { Förprojekt } \\
\text { Kontrakt: Heilsufrøðiliga Starvsstovan, FO } \\
\text { Publikation: Kopierad rapport (15 s) }\end{array}$ & $\mathrm{P}$ & $x$ & & \\
\hline & 1993 & $\begin{array}{l}\text { Renere teknologi, Islandsk case study } \\
\text { Kontrakt: Islands Teknologiske Institut, IS } \\
\text { Publikation: Cleaner Production Technology. } \\
\text { TemaNord 1994:606 (45 s). } \\
\text { http://www.norden.org/pub/sk/showpub.asp?pubnr=1994:606 } \\
\text { (Utsåld, inte nedladdningsbar) }\end{array}$ & $\mathrm{P}$ & & $x$ & \\
\hline & 1994 & $\begin{array}{l}\text { Behandling af organisk husholdningsaffald i tyndtbe- } \\
\text { folkede isolerede områder } \\
\text { Kontrakt: Islands Teknologiske Institut, IS } \\
\text { Publikation: Organic Household and Garden Waste - Treat- } \\
\text { ment in Sparsely Populated Isolated Communities. TemaNord } \\
\text { 1994:611 (64 s) } \\
\text { http://www.norden.org/pub/sk/showpub.asp?pubnr=1994:611 } \\
\text { (Utsåld, inte nedladdningsbar) }\end{array}$ & $\mathrm{P}$ & $x$ & & \\
\hline 1992 & 1994 & $\begin{array}{l}\text { Miljøfarligt affald i ø-samfund } \\
\text { Kontrakt: Teknokon pf, FO } \\
\text { Publikation: Registrering af miljøfarligt affald i et isoleret øsam- } \\
\text { fund. TemaNord 1994:612 } \\
\text { (52 s) } \\
\text { http://www.norden.org/pub/sk/showpub.asp?pubnr=1994:612 } \\
\text { (Utsåld, inte nedladdningsbar) }\end{array}$ & $\mathrm{P}$ & $x$ & & \\
\hline 1993 & 1994 & $\begin{array}{l}\text { Kortlægning af affaldshåndtering i nordiske ø-samfund } \\
\text { Kontrakt: Tegnestuen } 3 \text { D-Miljø, Bornholm DK } \\
\text { Publikation: Kortlægning af affaldshåndtering i nordiske ø- } \\
\text { samfund. TemaNord 1997:522 } \\
\text { (60 s) } \\
\text { http://www.norden.org/pub/sk/showpub.asp?pubnr=1997:522 } \\
\text { (Kan beställas, inte nedladdningsbar) }\end{array}$ & $P$ & $x$ & & \\
\hline \multirow[t]{3}{*}{1994} & 1994 & $\begin{array}{l}\text { Affaldsbehandling i nordiske ø- og småsamfund } \\
\text { Workshop på Eyði, Färöarna, augusti } 1994 \\
\text { Kontrakt: Heilsufrøðiliga Starvsstovan, FO } \\
\text { Publikation: Kopierat rapport till deltagare och RT-gruppen }\end{array}$ & WS & $x$ & & \\
\hline & 1996 & 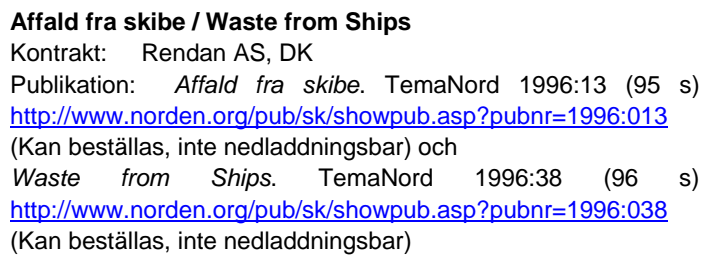 & $\mathrm{P}$ & $x$ & & \\
\hline & 1996 & $\begin{array}{l}\text { Forsøg med hjemmekompostering på Færøerne og i Island } \\
\text { Kontrakt: Islands Teknologiske Institut, IS } \\
\text { Publikation: Hjemmekompostering i Island og på Færøerne. } \\
\text { TemaNord 1996:609 (96 s) } \\
\text { http://www.norden.org/pub/sk/showpub.asp?pubnr=1996:609 } \\
\text { (Kan beställas, inte nedladdningsbar) }\end{array}$ & $\mathrm{P}$ & $x$ & & \\
\hline
\end{tabular}




\begin{tabular}{|c|c|c|c|c|c|c|}
\hline \multirow[b]{2}{*}{ Start } & \multirow[b]{2}{*}{ Slut } & \multirow[b]{2}{*}{ Titel och beskrivning } & \multicolumn{3}{|c|}{ Fokus } & \multirow[b]{2}{*}{ 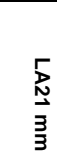 } \\
\hline & & & $\sum_{i}^{D}$ & 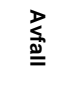 & $\frac{8}{\frac{m}{m}}$ & \\
\hline & 1996 & $\begin{array}{l}\text { Hjemmekompostering } \\
\text { Kontrakt: Islands Teknologiske Institut, IS } \\
\text { Publikation: Hjemmekompostering - Et klogt valg i affaldsbe- } \\
\text { handling. TemaNord 1997:568 (30 s) } \\
\text { http://www.norden.org/pub/sk/showpub.asp?pubnr=1997:568 } \\
\text { (Kan beställas, inte nedladdningsbar) och } \\
\text { Hjemmekompostering - Brugervejledning om hjem- } \\
\text { mekompostering. TemaNord 1997:569 (30 s) } \\
\text { http://www.norden.org/pub/sk/showpub.asp?pubnr=1997:569 } \\
\text { (Kan beställas, inte nedladdningsbar) }\end{array}$ & $P$ & $x$ & & \\
\hline 1996 & 1997 & $\begin{array}{l}\text { Miljøet i kommunerne } \\
\text { Kontrakt: Heilsufrøðiliga Starvsstovan, FO } \\
\text { Publikation: Plan for miljøet i kommunene, Kommunale miljø- } \\
\text { handlingsplaner i småsamfund. TemaNord 1997:576 (112 s) } \\
\text { http://www.norden.org/pub/sk/showpub.asp?pubnr=1997:576 } \\
\text { (Kan beställas, inte nedladdningsbar) }\end{array}$ & $P$ & & & $x$ \\
\hline \multirow[t]{3}{*}{1997} & 1997 & $\begin{array}{l}\text { Miljøseminarer på Færøerne og i Island } \\
\text { Miljöseminarier, Tórshavn FO } \quad 28-30 \quad \text { maj } \\
\text { och Egilsstaðir IS 9-10 juni } 1997 \\
\text { Kontrakt: Heilsufrødiliga Starvsstovan, FO } \\
\text { Publikation: Kopierad rapport till deltagare och RT-gruppen }\end{array}$ & wS & $x$ & $x$ & $x$ \\
\hline & 1997 & $\begin{array}{l}\text { Miljøstyring med resultat } \\
\text { Kontrakt: Islands Teknologiske Institut, IS } \\
\text { Publikation: Håndbog om miljøstyring, Grøn fortjeneste, } \\
\text { Miljøstyring med resultat. } \\
\text { TemaNord 1997:597 (116 s) } \\
\text { http://www.norden.org/pub/sk/showpub.asp?pubnr=1997:597 } \\
\text { (Kan beställas, inte nedladdningsbar) }\end{array}$ & $P$ & & $x$ & \\
\hline & 1998 & $\begin{array}{l}\text { Undervisningsmateriale om miljøledelse i virksomheder } \\
\text { Kontrakt: Islands Teknologiske Institut, IS } \\
\text { Publikation: Grøn fortjeneste, Undervisningsmateriale om } \\
\text { miljøledelse i virksomheder. } \\
\text { TemaNord 1999:562 (154 s) } \\
\text { http://www.norden.org/pub/sk/showpub.asp?pubnr=1999:562 } \\
\text { (Kan beställas, inte nedladdningsbar) }\end{array}$ & $P$ & & $x$ & \\
\hline \multirow[t]{3}{*}{1997} & 1998 & $\begin{array}{l}\text { Miljøstyring i småsamfund } \\
\text { Förprojekt } \\
\text { Kontrakt: Rendan AS, DK } \\
\text { Publikation: Godt begyndt - miljøstyring i virksomheder i små- } \\
\text { og ø-samfund. TemaNord 1999:569 (87 s) } \\
\text { http://www.norden.org/pub/sk/showpub.asp?pubnr=1999:569 } \\
\text { (Kan beställas, inte nedladdningsbar) }\end{array}$ & $P$ & & $x$ & \\
\hline & 1998 & $\begin{array}{l}\text { Skærpede krav til deponering af affald } \\
\text { Kontrakt: Rendan AS, DK } \\
\text { Publikation: Slutbehandling af affald i små- og ø-samfund. Eu's } \\
\text { skærpede krav til deponering og mulige omlægninger af af- } \\
\text { faldsbehandlingen som konsekvens heraf. TemaNord 2000:507 } \\
\text { (213 s) } \\
\text { http://www.norden.org/pub/sk/showpub.asp?pubnr=2000:507 } \\
\text { (Kan beställas, inte nedladdningsbar) }\end{array}$ & $P$ & $x$ & & \\
\hline & 1999 & $\begin{array}{l}\text { Befolkningens holdninger til affaldshåndtering i småsamfund } \\
\text { Kontrakt: PRess AS, NO } \\
\text { Publikation: Holdninger til avfallshåndtering i nordiske små- } \\
\text { samfunn. TemaNord 1999:570 (50 s) } \\
\text { http://www.norden.org/pub/sk/showpub.asp?pubnr=1999:570 } \\
\text { (Kan beställas, inte nedladdningsbar) }\end{array}$ & $P$ & $x$ & & \\
\hline
\end{tabular}


Tabell 2. Projekt och workshops genomförda av Småsamfundsgruppen i perioden 2000-2007. (P-projekt, WS-workshop/seminar, CP-Renare Teknologi (Cleaner Production), EMS-Miljöstyrning (Environmental Management), LA21=Lokal Agenda 21).

\begin{tabular}{|c|c|c|c|c|c|c|}
\hline \multirow[b]{2}{*}{ Start } & \multirow[b]{2}{*}{ Slut } & \multirow[b]{2}{*}{ Titel och beskrivning } & \multicolumn{2}{|c|}{ Fokus } & \multirow[b]{2}{*}{$\frac{n}{\frac{1}{3}}$} & \multirow[b]{2}{*}{$\begin{array}{l}\underset{\mathbb{N}}{5} \\
\mathbf{3}\end{array}$} \\
\hline & & & $\sum_{\xi \infty}^{D}$ & 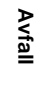 & & \\
\hline 2000 & 2000 & $\begin{array}{l}\text { Lokal Agenda } 21 \text { i Nordens småsamfund } \\
\text { Workshop i Tórshavn 2-3 november } 2000 \\
\text { Ursprungligen hade workshopen rubriken "Kretslopps-samfundets } \\
\text { Agenda 21" men fick under förberedningen den ovanstående titeln med } \\
\text { undertitel "Hvilke erfaringer har ø- og småsamfundene i Norden gjort sig } \\
\text { omkring Lokal Agenda } 21 \text { arbejdet?". Syftet var att skapa ramarna för ett } \\
\text { forum där aktörer inför LA21 arbetet i ö- och småsamfund kunde mötas } \\
\text { och utväxla erfarenheter. } \\
\text { Kontrakt: Heilsufrøðiliga Starvsstovan, FO } \\
\text { Publikation: Ingen publikation }\end{array}$ & $\begin{array}{l}\text { W } \\
\mathrm{s}\end{array}$ & & & $x$ \\
\hline 2001 & 2001 & $\begin{array}{l}\text { Initiering af Agenda } 21 \text { i småsamfund } \\
\text { Formålet med projektet var at øge færøske og islandske kommuners } \\
\text { kundskaber med henblik på at engagere lokalsamfundet i LA21 arbejdet. } \\
\text { For at opnå formålet blev der afholdt workshoper i oktober-november } \\
2001 \text {, omkring et "rejsehold" af foredragsholdere, der rejste rundt og } \\
\text { besøgte } 3 \text { færøske og } 3 \text { islandske kommuner. Foredragsholderne kom } \\
\text { fra Steigen i nord Norge, Hven i Sverige, Hveragerdi i Island og Vest- } \\
\text { manna på Færøerne og var alle aktive i det daglige arbejde med LA21 i } \\
\text { kommunalt regi i sine hjemmebygder. } \\
\text { På Færøerne besøgte holdet Sundalagi, Klaksvík og Vestmanna, udover } \\
\text { et offentligt foredrag i Torshavn. På Island besøgte holdet Siglufjordur, } \\
\text { Grundarfjordur og Ölfus. Deltagerne på workshopen var kommunalpoliti- } \\
\text { kere, kommuneansatte, samt evt. frivillige miljøorganisationer i kommu- } \\
\text { nen. } \\
\text { Kontrakt: Heilsufrøðiliga Starvsstovan, FO } \\
\text { Publikation: En intern summering från workshopen för Småsamfunds- } \\
\text { gruppen och PA-gruppen }\end{array}$ & $\begin{array}{l}\text { W } \\
\mathrm{s}\end{array}$ & & & $\mathrm{x}$ \\
\hline 2001 & 2002 & $\begin{array}{l}\text { LA21 Idéhæfte } \\
\text { Formålet med projektet var at bidrage til synliggørelse og styrkelse af de } \\
\text { stadig voksende aktiviteter knyttet til Lokal Agenda } 21 \text { rundt i de } \\
\text { nordiske småsamfund. Dette blev gjort ved at fremstille et idéhæfte om } \\
\text { bæredygtig udvikling og LA 21. Materialet i hæftet indeholder en generel } \\
\text { introduktion til bæredygtig udvikling og Agenda } 21 \text { og forsøger at frem- } \\
\text { hæve det ansvar og de muligheder, der ligger hos kommunerne. } \\
\text { Kontrakt: Alta ehf, IS } \\
\text { Publikation: LA Idéhæfte. ANP 2003:758 } \\
\text { (80 s) } \\
\text { http://www.norden.org/pub/sk/showpub.asp?pubnr=2003:758 }\end{array}$ & $\mathrm{P}$ & & & $\mathrm{x}$ \\
\hline 2004 & 2004 & $\begin{array}{l}\text { Lokal Agenda } 21 \text { idéverkstäder } \\
\text { Idéverkstädernas syfte var att presentera och lyfta fram goda idéer och } \\
\text { exempel ur LA21 Idéhäftet. Meningen var att utnyttja och utgå ifrån de } \\
\text { kontakter som finns i Idéhäftet och inspirera framtida Agenda 21-arbete i } \\
\text { nordiska småsamfund. Idéverkstäder hölls på följande ställen 2004: } \\
\text { Lemland AX 29/8, Ålesund NO } 7 / 9 \text {, Akureyri IS 10/9, Tórshavn FO 17/9, } \\
\text { Västanfjärd F 9/10, Thisted DK } 23 / 10 \text {, Grästorp S 15/11. En ytterligare } \\
\text { idéverkstad hölls í llullissat, Grönland } 27 / 82005 . \\
\text { Kontrakt: Ålands Natur och Miljö, AX } \\
\text { Publikation: Lokala Agenda } 21 \text { Idéverkstäder i Norden. Intern rapport till } \\
\text { deltagare och PA-gruppen }\end{array}$ & $\begin{array}{l}\text { W } \\
\mathrm{s}\end{array}$ & & & $x$ \\
\hline 2004 & 2005 & 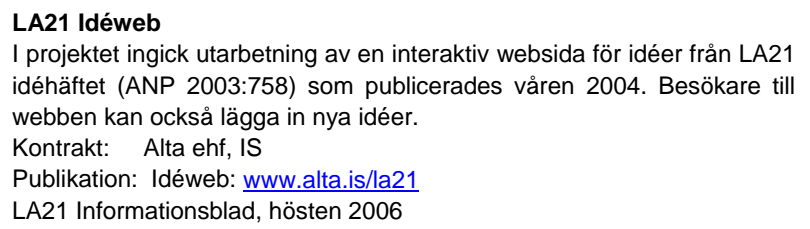 & $\mathrm{P}$ & & & $x$ \\
\hline 2005 & 2006 & Miljøledelse for SME i Norden - Forslag til en indsats i småsamfund & $\mathrm{P}$ & & $\mathrm{X}$ & \\
\hline
\end{tabular}




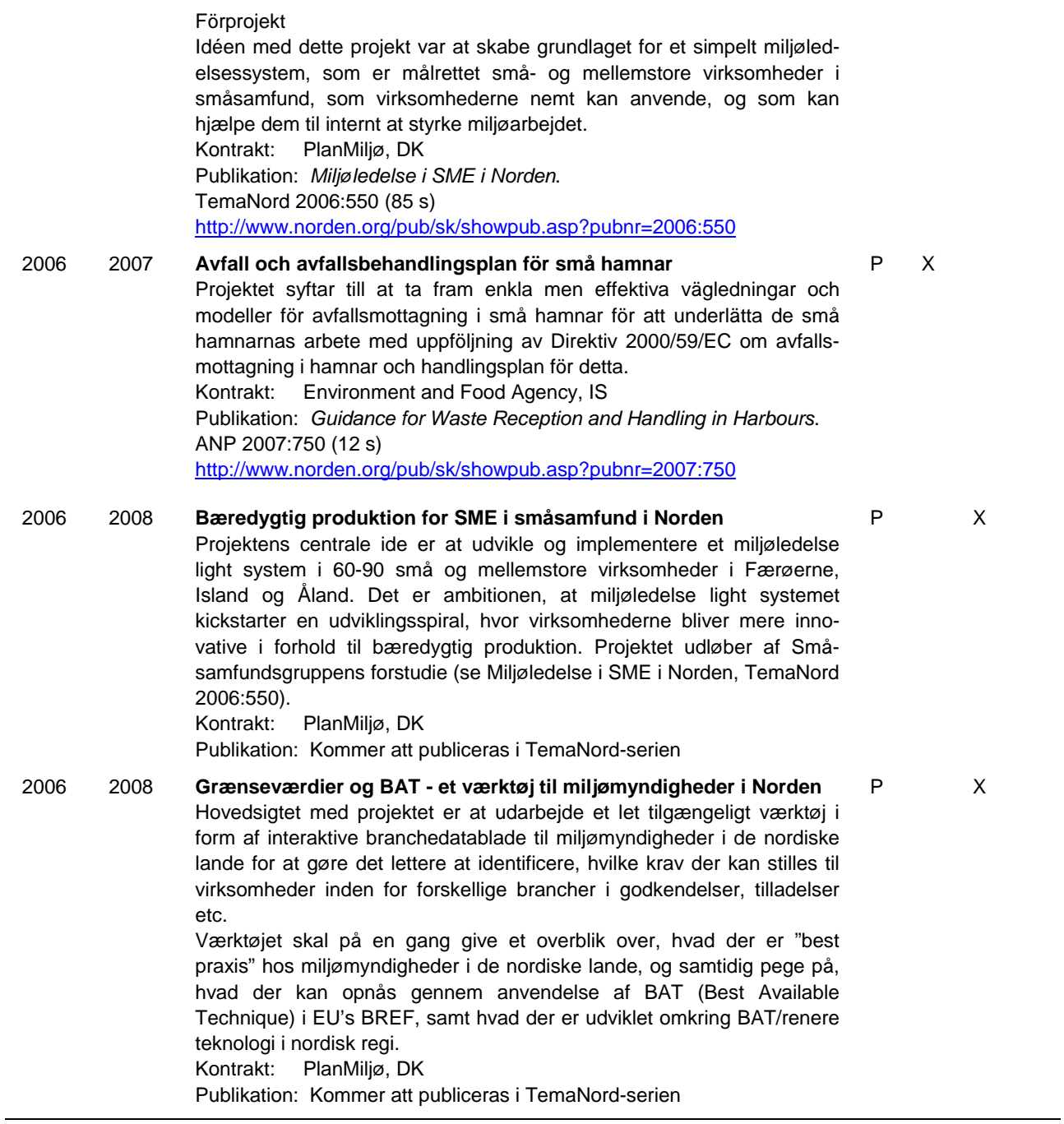

Som framkommit var Småsamfundsgruppens fokus under perioden 19911999 främst på avfallsfrågor, men också i viss mån på renare teknologi och miljöstyrning. Under den första hälften av perioden 2000-2007 stod Lokal Agenda 21 centralt i gruppens arbete, men under de sista två åren har gruppens fokus igen varit främst på miljöstyrning. Det kan således konstateras att det under olika tidsperioder funnits olika röda trådar i gruppens arbete, från avfall 1991-1999, till Lokal Agenda 21 2000-2005 och miljöstyrning 2006-2007. Bild 4 ger en schematisk översikt över dessa trender.

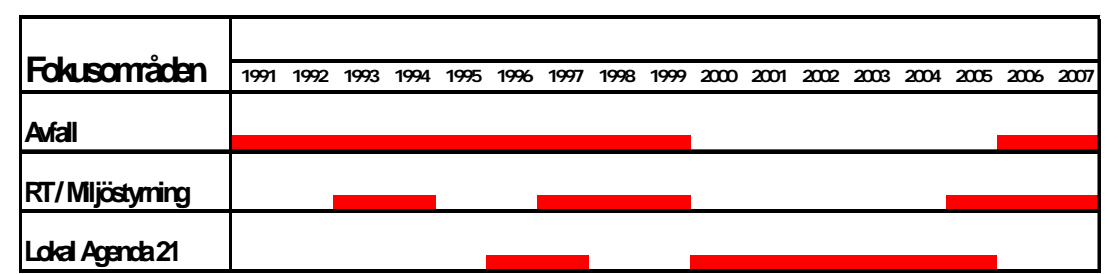

Bild 3. “Röda trådar” i Småsamfundsgruppens arbete 1991-2007. 
Småsamfundsgruppens arbete med avfallsfrågor i perioden 1991-1999 kan i stora drag delas upp i tre kategorier. Den första handlar generellt om avfallsbehandling i nordiska ö- och småsamfund, den andra om behandling av organiskt avfall och den tredje om diverse avfallsfrågor, härunder miljöfarligt avfall och avfall från skepp. Huvuddelen av detta arbete skedde faktiskt under perioden 1991-1996, men de två sista projekten genomfördes under 1998 och 1999. Inga mätbara bedömningar finns av avfallsprojektens nytta, men som ett exempel kan det nämnas att broschyrerna om hemmakompostering som utgavs i 1996 fick en stor spridning på Island. Generellt kommer nästan alla projekt till nytta i det dagliga arbetet hos nationella myndigheter på området. Denna typ av nytta är mycket viktig men samtidigt svår att mäta.

Småsamfundsgruppen har arbetat med renare teknologi och miljöstyrning under två olika perioder. Ett projekt om renare teknologi som genomfördes 1993 kan ses som en förberedning för de aktiviteter som gruppen hade på gång under perioden 1997-1999. Under denna period producerade gruppen bl.a. en handbok och undervisningsmaterial om miljöstyrning, vilken fortfarande finns på olika bokhyllor i Norden. Just nu befinner sig gruppen i den senare perioden. Nu har fokus flyttats från vägledning till mer övergripande miljöstyrningssystem för små och mellanstora företag.

Småsamfundsgruppens arbete med Lokal Agenda 21 började under 1996-1997 med ett projekt om en miljöhandlingsplan för småsamfund. Fokus för detta var faktiskt inte direkt hållbar utveckling och LA21, men metodiken och själva arbetet bildade en grund för arbetet med LA21 på nationell nivå på Island, vilket fortfarande pågår. En senare period i gruppens satsning på LA21 hade sin höjdpunkt under 2003-2005 med publiceringen av det nordiska LA21 idéhäftet och den motsvarande idéwebben. Idéhäftet har varit mycket efterfrågat och har tryckts i två gångar. Bl.a. tog deltagare i de två första nordiska konferenserna om lokal hållbarhet, i Göteborg 2004 och Oslo 2006, med sig en stor upplaga av häftet, vilket fanns på plats under båda konferenserna. Sim tillägg till och i samband med gruppens arbete med idéhäftet och idéwebben stod gruppen i denna "senare period" totalt för 16 workshops och möten om LA21 i samtliga nordiska länder.

\subsection{Småsamfundsgruppens framtid}

Som framkommit utlöper Småsamfundsgruppens mandat i slutet av 2008. Samtidigt utlöper samtliga styrdokument som är mest aktuella för gruppen (jfr. bild 2). Det är därför viktigt att gruppen samt användarna av gruppens processer och produkter sätter sig ner och diskuterar vägen vidare. Den nordiska workshopen i Hafnarfjordur 25-26 oktober 2007 var ett viktigt steg i detta. 
Underlagsdokumentet som framlades i början av workshopen innehöll inte några förslag till Småsamfundsgruppens framtida arbete. I stället fick workshopens deltagare den viktiga uppgiften att utarbeta sådana förslag. Detta var dock ingen lätt uppgift, eftersom det vid den tidpunkten inte förelåg någonting om Nordiska Ministerrådets framtida satsningar inför områden miljö och hållbar utveckling, vilka kommer att återspeglas i en reviderad BU-strategi samt i ett reviderat miljöhandlingsprogram. Revideringen av dessa två grundläggande dokument är i skrivande stund fortfarande i en startfas.

Samtidigt som den parallella revideringen av olika styrdokument medför problem och osäkerhet gällande Småsamfundsgruppens framtid, så bör den ses som ett tillfälle att påverka policyutvecklingen. Det är ingen definitiv sanning att hönan måste komma före ägget. De sex frågorna som workshopdeltagarna ombads hitta svar på är lika aktuella, oavsett om det redan finns en övergripande strategi på en högre nivå eller inte. Frågorna kan faktiskt ses som ännu mer aktuella då den högre nivån inte fastställt linjerna för det framtida samarbetet. 


\section{Workshop i Hafnarfjörður 25-26 oktober 2007}

Som framkommit stod Småsamfundsgruppen för en intern workshop i Hafnarfjordur, Island den 25-26 oktober 2007 med syfte att skapa en bas för beslut om Småsamfundsgruppens fortsatta arbete. Workshopdeltagarna kom från de nordiska områden som varit mest aktiva i gruppens arbete.

\subsection{Deltagare}

Till workshopen inbjöds tre deltagare från varje land/område plus eventuella extra deltagare från övriga områden. Workshopen hölls på två halvdagar med övernattning. De följande deltog i workshopen:

Färöarna:

- Jákup Pauli Joensen, direktör Umhvørfisstovan, medlem av Småsamfundsgruppen

- Bergmann Finnsson, Agenda 21 rådgivare, Agenda 21 Stovan

- Janet Fríða Johannesen, direktör, Atlanticon konsulter

Island:

- Sigurbjörg Sæmundsdóttir, avdelningschef Miljöministeriet, Småsamfundsgruppens ordförande

- Anton Helgason, direktör Miljötillsynsmyndigheten, Vestfjordområdet

Norge:

- Evy Jørgensen, Seksjonsleder forurensning, Fylkesmannen i Finnmark, medlem av Småsamfundsgruppen

- Frode Karlsen, direktør i Øst-Finnmark Avfallsselskap ANS (ØFAS ANS)

- Gøsta Hagenlund, nestleiar, miljøvernavdelinga, Fylkesmannen i Sogn og Fjordane

Åland:

- Mona Kårebring Olsson, Miljöingenjör Miljöbyrån, Ålands landskapsregering, medlem av Småsamfundsgruppen

- Gunda Åbonde-Wickström, ordförande Ålands Natur och Miljö

- Fredrik Karlsson, verksamhetsledare för kommunernas avfallshantering, Ålands miljöservice 
Finland:

- Paula Mikkola, generalsekreterare, Nordkalottrådet

Environice:

- Stefán Gíslason, projektledare, workshopansvarig

- Birgitta Stefánsdóttir, workshopassistent

\subsection{Arbetsmetod}

Som framkommit togs det fram ett underlagsdokument inför workshopen. Detta användes som grund för diskussionen. Efter korta inledningar av Småsamfundsgruppens ordförande samt av projektledaren, delades workshopdeltagarna upp i fyra grupper med tre deltagare i varje. Två sådana gruppsessioner genomfördes under workshopens första dag, på en och en halv timme vardera. Vid dagens slut presenterades sedan de viktigaste resultaten i plenum. En tredje lika lång gruppsession genomfördes under dag två, vilken igen avslutades med presentationer från grupperna.

Var och en av de fyra workshopgrupperna leddes av en medlem av Småsamfundsgruppen. Gruppernas sammansättning ändrades efter varje gruppsession, således att ledaren fick in två nya individer i sin grupp, vilka heller inte hade suttit tillsammans i en tidigare grupp. På detta sätt deltog samtliga deltagare i tre helt olika grupper under workshopen. Ingen utvärdering gjordes av detta arbetssätt, men generellt uttalade workshopdeltagarna sig mycket positivt om detta och tyckte att denna "upprepade blandning" bidrog till ett maximalt utbyte av idéer mellan deltagarna.

I workshopen sökte deltagarna finna svar på de frågor som ställdes i början (jfr. kapitel 1) med ett par mindre tillpassningar, jfr. följande:

1. Har Småsamfundsgruppens arbete varit framgångsrikt? Vad har lyckats bra och vad har inte lyckats lika bra?

2. Finns det ett behov för gruppen i det framtida nordiska samarbetet?

3. I så fall, vilka skulle så vara gruppens fokusområden/huvuduppgifter?

4. Kan gruppens resultat få en bättre användning/spridning - på hemmaplan eller bland övriga aktörer/länder - direkt eller genom översättningar?

5. Borde samarbetet utvidgas för att täcka en större del av Norden?

6. Finns det ett potential för samarbete med små- eller ösamfund utanför Norden?

7. Hur kan småsamfundens intresser och utmaningar bäst ivaretas i en reviderad Nordisk strategi för hållbar utveckling, samt i ett nytt Nordiskt Miljöhandlingsprogram vilka planeras gälla för perioden 2009-2012? 
I varje gruppsession ombads varje grupp att diskutera en-tre av de sju frågorna. Således deltog samtliga deltagare i diskussion om samtliga frågor.

I de följande kapitlen sammanställs deltagarnas svar på de sju frågorna.

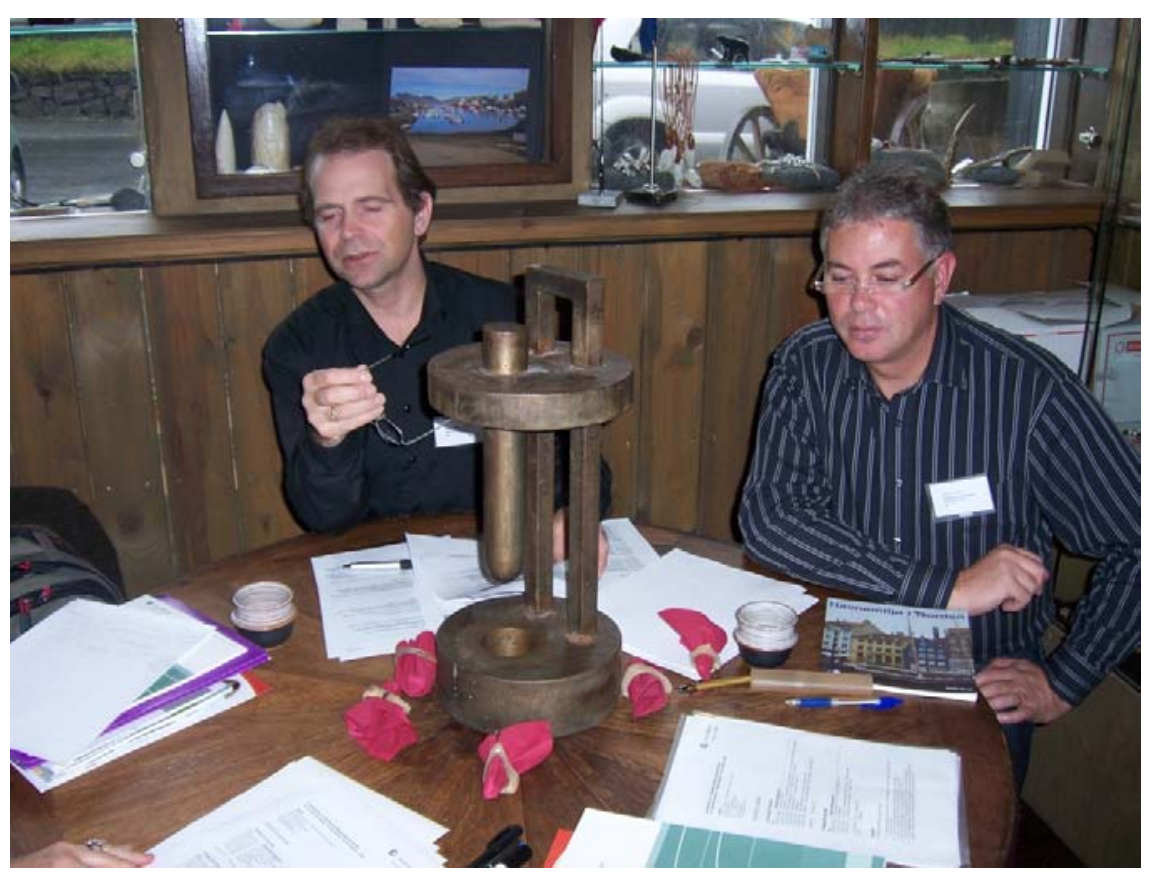

Bild 4. Från workshopen i Hafnarfjordur: Jákup Pauli Joensen från Färöarna och Anton Helgason från Island diskuterar vad som lyckats bra i Småsamfundsgruppens arbete hittills. (Bild: Stefán Gíslason) 



\section{Resultat}

I de följande avsnitten sammanställs workshopdeltagarnas svar till de olika frågorna. Rubrikerna svarar till frågorna ovan.

\subsection{Har Småsamfundsgruppens arbete varit framgångsrikt? Vad har lyckats bra och vad har inte lyckats lika bra?}

Småsamfundsgruppens arbete med Lokal Agenda 21 anses vara gruppens största succé. Arbetet med Lokal Agenda som startades på Island 1998 och som fortfarande är på gång, har rötter i Småsamfundsgruppens projekt om miljöhandlingsplaner i små kommuner 1996-1997. På samma sätt har arbetet medLokal Agenda på Färöarna haft stor nytta av Småsamfundsgruppens aktiviteter på området. Småsamfundsgruppens arbete anses således ha varit ett viktigt bidrag för att utvidga och sprida LA21arbetet i Norden.

Småsamfundsgruppens arbete med avfallsfrågor anses också ha varit mycket nyttigt, eftersom gruppen i flera fall bidragit till lösningar till den tidens aktuella avfallsproblem i nordiska småsamfund, t.ex. i samband med farligt avfall och kompostering. Resultaten från gruppens projekt har använts och bidragit till ökad kunskap och förståelse på området.

Småsamfundsgruppens arbete med miljöstyrning anses inte ha varit lika lyckat. Det verkar i alla fall inte finnas klara tecken på att resultaten från gruppens projekt på området på 90-talet spridits och använts. Gruppen verkar heller inte ha gjort någon utvärdering av projekten. Ett nytt initiativ startades alltså 2006 utan att gruppen tagit lärdom från projekten i den förra perioden.

Trots detta anses miljöstyrningsarbetet ha hjälpt till med spridning av nya tankar. De som varit med i detta arbete under både projektperioderna har konstaterat att företagen inte var beredda för denna typ arbete på 90talet. Nu skiljer sig förutsättningarna däremot mycket jämfört med för 10 år sedan och förfrågningar efter olika verktyg för företagens miljöarbete har ökat stort.

Viktigheten av Småsamfundsgruppens arbete ligger inte minst $\mathrm{i}$ arbetets sektorövergripande natur, vilken avspeglas särskilt klart i LA-21satsningen. PA-gruppens övriga undergrupper är starkt sektorinriktade och samma gäller arbetet på EU-nivå, härunder EU-regelverket. Just på grund av detta behövs det en mer sektorövergripande insats när det gäller småsamfund. Småsamfundsgruppen har lyckats att sätta fokus på lokal- 
miljöns särskilda förutsättningar i olika frågor och få till diskussion om hur enskilda element i EU-direktiven m.m. kan tillämpas i småsamfunden, bl.a. med hänsyn till eventuella undantag. Visst skall småsamfunden uppfylla samma krav som de andra inom EU, om dock på ett annat sätt. Gruppens arbete har givit inspiration till innovativa lösningar i detta sammanhang.

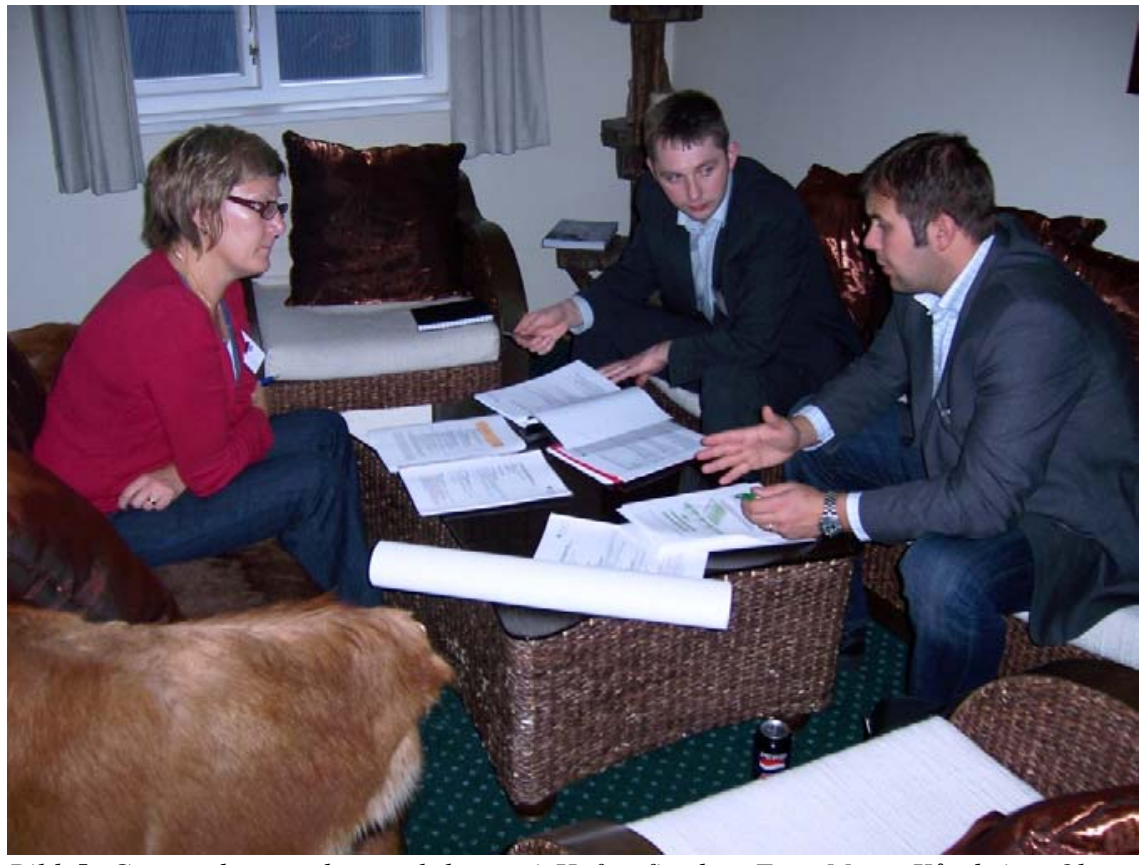

Bild 5. Grupparbete under workshopen i Hafnarfjordur. F.v.: Mona Kårebring Olsson från Åland, Bergmann Finnsson från Färöarna och Frode Karlsen från Norge. (Bild: SG)

I tillägg till det som nämnts ovan har Småsamfundsgruppen fungerat mycket bra som en plattform för utväxling av idéer och erfarenheter mellan de deltagande områdena. Här har man t.ex. kunnat jämföra sig med de andra ang. tolkning och implementering av EU-regler o.s.v. Samarbetet har således i praktiken förkortat avståndet mellan de som jobbar med småsamfundsproblematiken i de olika länderna/områdena. Denna nytta är inte lätt att mäta, men det verkar råda stor enighet om att detta har hjälpt mycket i det nationella arbetet.

Det som inte tycks ha lyckats lika bra är spridningen av det "goda budskapet”, såsom till lokalförvaltningar, branschorganisationer och enskilda företag. Det behövs också en större insats för att föra "upp” synsättet till sektormyndigheter på nationell och/eller EU-nivå. De publicerade rapporterna har heller inte alla varit lika tillgängliga, inte minst med hänsyn till format. En typisk TemaNord-rapport med mycket text och lite bilder har ingen större chans att nå ut till målgruppen, medan en publikation som t.ex. Lokal Agenda 21 Idéhäftet (ANP 2003:758) har större möjligheter p.g.a. dess tillgängliga layout. Småsamfundsgruppens produkter måste göras tillgängliga i situationer där intresse finns! 


\subsection{Finns det ett behov för gruppen i det framtida nordiska samarbetet?}

Workshopdeltagarna var alla eniga $\mathrm{i}$ att det finns ett fortsatt behov av Småsamfundsgruppen i det framtida nordiska samarbetet. Det kommer nämligen alltid att finnas speciella uppgifter som inte kan lösas på samma sätt i småsamfund som i de stora samhällena. Detta kräver dock att gruppen har ett brukbart mandat, d.v.s. att mandatet tillåter den flexibilitet som behövs för att kunna ta tag i speciella problemställningar som dyker upp mitt i mandatperioden, t.ex. i samband med implementering av EUdirektiv.

I samband med diskussionen om Småsamfundsgruppens uppgifter framöver behövs det eventuellt en klarare definition av begreppet "småsamfund”.

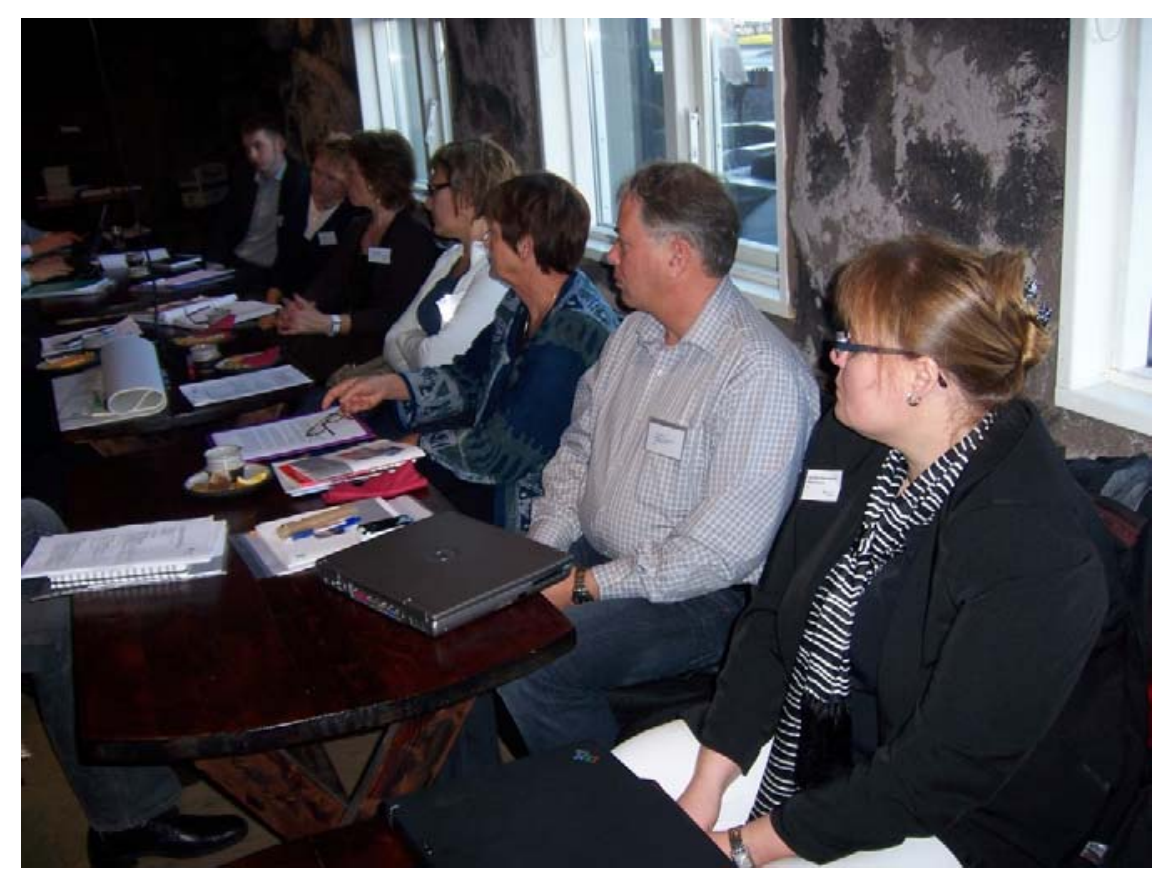

Bild 6. Från en av plenumsessionerna under workshopen i Hafnarfjordur. (Bild: SG)

\subsection{I så fall, vilka skulle så vara gruppens fokusområden/ huvuduppgifter?}

Som framkommit anses det vara viktigt att Småsamfundsgruppen har tillräcklig flexibilitet för att kunna ta tag i aktuella uppdrag i dagsläget. Huvuduppgifterna borde som sagt eventuellt inte vara helt spikade. Bland de mest aktuella områden finns det dock:

1. Klimataspekter

2. Miljögifter 
3. Fiskodling

4. LA21-kontinuitet

5. Avfall, bl.a.:

- Avfall från turism

- Rivningsavfall

- Organiskt avfall (småskala/lukt/transport)

- Avfall från notvaskerier (koppar m.m.)

- Möjligheter (idépark) för lokal avfallsbehandling

- Avlopp och avloppsrecipienter

- Miljöstyrningssystem samt certifiering av dessa

- Grön inköp

- Hållbar konsumtion

- Industriell ekologi

På det stora hela anses gruppen kunna fortsätta med liknande uppgifter som hittills. I alla fall bör gruppen fortsatt fokusera på miljö- och hållbarhetsfrågor som är relevanta för nordiska småsamfund. Gruppen bör göras mer synlig i det nordiska miljösamarbetet.

En idé som framkom var att man gör en utvärdering av de mest aktuella problemställningarna och sedan utarbetar en ny problembeskrivning. I tillägg till detta kunde Småsamfundsgruppen löpande granska de aktiviteter som PA-gruppens övriga undergrupper har på gång och identifiera vilka av dessa som behöver särskild tillpassning till småsamfund. Småsamfundsgruppen kunde genom detta tillvarata småsamfundens speciella intressen i olika sammanhang, t.ex. i samband med implementering av EU-direktiv. Möjligen kunde detta omfatta ett ännu bredare spektrum, genom att göra en liknande granskning av projekt och aktiviteter under övriga fasta arbetsgrupper under ÄK-M, d.v.s. Hav- och luftgruppen, Kemikaliegruppen, NFK-gruppen och NMD-gruppen. Detta samarbete med de övriga arbetsgrupperna behöver inte endast vara ensidigt, utan Småsamfundsgruppen kan också framlägga idéer och förslag för grupperna att jobba vidare med. Gruppen kunde faktiskt fungera som ett "talrör” mellan småsamfund och regeringer, i båda riktningar.

Småsamfundsgruppen kunde möjligen arbeta mer proaktivt när det gäller utarbetning av EU-direktiv. Den kunde således redan i förberedningsfasen ge fackliga inspel till EU för att främja hänsyn till lokala och regionala aspekter när direktiven utarbetas. Detta kan göras genom en facklig dialog med nationella experter som deltar i utarbetningen, men som inte nödvändigtvis känner till småsamfundens speciella förhållanden.

Nätverksbyggning är och bör fortsatt vara en viktig del av gruppens arbete. Även den workshop som beskrivs i detta dokument har bidragit till etablering av nya kontakter mellan nordiska småsamfund, som annars inte skulle ha funnits.

Småsamfundsgruppens namn diskuterades $\mathrm{i}$ en av grupperna under workshopen, utan att det framkom något nytt förslag m.h.t. detta. 


\subsection{Kan gruppens resultat få en bättre användning/spridning - på hemmaplan eller bland övriga aktörer/länder - direkt eller genom översättningar?}

Som framkommit anses informationsspridningen vara den svagaste delen av gruppens verksamhet. Detta kunde alltså visserligen förbättras. I detta sammanhang framkom det några aktuella idéer/förslag:

- Småsamfundsgruppen bör ha en bättre hemsida som fungerar bl.a. som en upplysningstavla för gruppens olika projekt och aktiviteter. Själva adressen är inte det viktigaste, men sidans innehåll, samt dess tillgänglighet. Tillgängligheten kan bäst säkras genom att alla relevanta institut har länkar till sidan på sina hemsidor. Detta gör också gruppens hemsida mer "populär" i sökmaskiner. Information på sidan bör vara mer resultatorienterad i stället för att fokusera på organisering och formaliteter.

- Småsamfundsgruppen bör i ökad grad producera vägledning och information till företag och småkommuner om lösningar till aktuella uppgifter, t.ex. gällande EU-direktiven.

- Gruppens medlemmar bör ta på sig en större roll som "informationsspridningsagenter” på nationell nivå, bl.a. genom att informera om gruppens arbete i föredrag och annan kommunikation inför sina respektive forum.

- Miljösektorn i Nordiska Ministerrådet kunde arrangera årliga informationsseminarier.

Spridning av information om Småsamfundsgruppens arbete kring Lokal Agenda 21 i form av seminarier, idéhäfte och idéwebb, anses vara ett bra exempel på en framgångsrik insats på informationsområdet.

Det föreslogs att Småsamfundsgruppen organiserar möten med representanter från kommuner för att skapa en översikt över aktuella problemställningar i småsamfunden samt för att sprida ut information om gruppens arbete. Detta kunde göras nationellt i en första omgång som förberedelse och fortsättningsvis sedan på nordisk nivå. Det anses även finnas behov av förbättringar av samarbetet mellan företag och offentliga myndigheter i samband med gruppens aktiviteter.

I diskussionen framkom att det är viktigt för användarna att kunna hitta aktuella problembeskrivningar och lösningsförslag på internet på ett enkelt sätt. Raporttitlar är inte alltid särskilt beskrivande.

När det gäller översättningar, så beror behovet på målgruppen. I vissa fall borde allt material översättas, även t.ex. mellan norska och svenska. Generellt skulle översättningar bidra till bättre användning eller spridning av resultaten. Behovet eller nyttan av översättningar till icke-nordiska språk, t.ex. engelska eller baltiska språk, borde övervägas för varje tillfälle. 
I många fall kunde man få mer för pengarna genom att bevilja medel till översättningar i stället för tryckning av rapporter. Möjligheten till automatiska översättningar borde övervägas.

\subsection{Borde samarbetet utvidgas för att täcka en större del av Norden?}

Workshopdeltagarna tyckte att det nordiska samarbetet kring småsamfundsproblematiken borde utvidgas för att täcka en större del av Norden. Gruppen borde således öppnas för andra regioner, men däremot borde man inte lägga för stor vikt vid att få dessa med, förutom kanske Grönland. Det påpekades att med undantag av Grönland har enskilda gruppmedlemmar goda kontakter med de flesta mest relevanta regionerna. Bättre informationsspridning (jfr. ovan) kan vara nyckeln till att väcka intresse i regionala enheter. Grönland, Norra Sverige, Norra Finland, Gotland och de danska öarna nämndes som regioner i detta sammanhang. Detta är dock också en fråga om resurser, härunder om att hitta personer med facklig kompetens och intresse för det nordiska samarbetet.

Samarbetet kan också utvidgas genom projektsamarbete, även om nya regioner inte direkt deltar i Småsamfundsgruppens arbete. Samarbetspartners kan t.ex. vara NGO:er och regionala organisationer så som Nordkalottrådet, Västnorden och Baltic Islands Network (B7), vilket är ett samarbete mellan de sju största öarna i Östersjöregionen (dvs. Gotland, Öland, Åland, Bornholm, Rügen, Hiiumaa och Saaremaa).

\subsection{Finns det ett potential för samarbete med små- eller ösamfund utanför Norden?}

Workshopdeltagarna tyckte att potential för samarbete med små- eller ösamfund utanför Norden främst kan finnas i projektform, samt i form av informationsutväxling. I varje fall bör man dock redan i förberedningsfasen argumentera för varför små- eller ösamfund utanför Norden bör tas med och visa hur samarbetet kan fungera i praktiken. Detta är dock en politisk fråga. Svaret till denna bör förankras i Nordiska Ministerrådets prioriteringar och strategier.

Samarbete med små- eller ösamfund utanför Norden har antagligen mest relevans för de följande geografiska områdena:

- Östersjöområdet, inkl. St. Petersburg, (jfr. också Baltic Islands Network (B7) ovan)

- Nordatlanten, inkl. Skottland (Shetland) och Irland

- Barentsområdet 
Ökat samarbete utanför Norden medför självklart större språkproblem, särskilt om man inkluderar ytterligare språkområden.

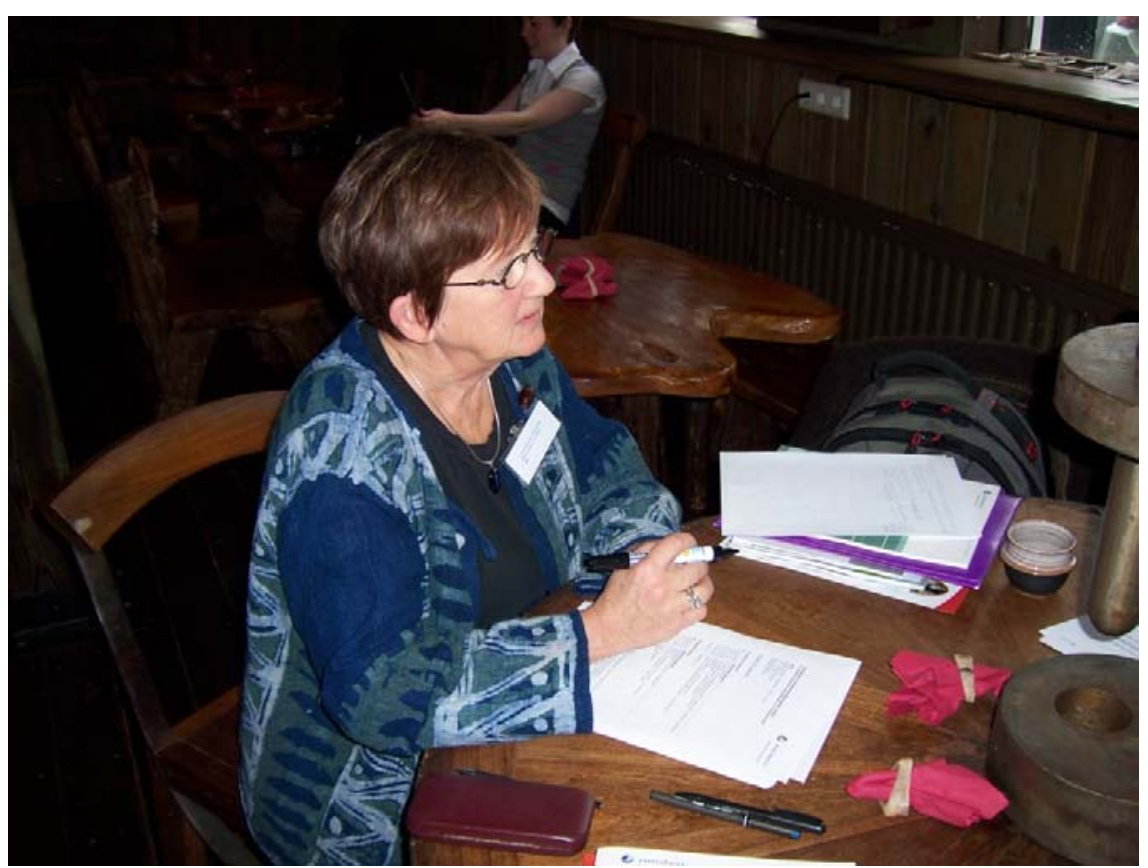

Bild 7. Från workshopen i Hafnarfjordur: Gunda Åbonde-Wickström, ordförande Ålands Natur och Miljö. (Bild: SG)

\subsection{Hur kan småsamfundens intresser och utmaningar bäst ivaretas i en reviderad Nordisk strategi för hållbar utveckling, samt i ett nytt Nordiskt Miljöhandlings- program vilka planeras gälla för perioden 2009-2012?}

Småsamfund utgör en stor del, eller faktiskt den geografiska huvuddelen av Nordens territorium. Med utgångspunkt i detta är det särskilt viktigt att småsamfundens intressen och utmaningar avspeglas i Nordiska Ministerrådets strategier och handlingsprogram, samt i implementeringen av dessa. Information om viktigheten av detta måste i sin helhet föras upp på miljöministernivå, både nationellt och nordiskt. I samband med detta är det viktigt att Småsamfundsgruppens medlemmar informerar sina respektive miljöministrar om gruppens arbete.

Det är viktigt att Småsamfundsgruppens framgångsrika arbete med Lokal Agenda 21 fortfarande får plats i ett reviderat Miljöhandlingsprogram. I tillägg till detta bör klimataspekter i samband med produkter och avfall i småsamfundssammanhang ingå i programmet, samt vård av speciella naturområden och biologisk mångfald i småsamfund, inte minst med hänsyn till turismindustrin. Bland övriga nyckelord kan nämnas:

1. Ekoturism i småsamfund

- Avlopp - avloppsrecipienter - lokala lösningar 
- Vattenvård, bl.a. m.h.t. Vattendirektivet (2000/60/EC)

Småsamfundsgruppen borde ta fram ett policydokument för att identifiera vilka aspekter som är viktiga i småsamfundssammanhang, samtidigt som man beskriver gruppens arbete hittills och hur man vill gå vidare. Ett sådant dokument kunde vara ett nyttigt inspel till revideringen av den Nordiska strategin för hållbar utveckling, samt av Miljöhandlingsprogrammet. Småsamfundsgruppen bör vara proaktiv i sitt arbete i samband med revideringen. 


\section{Slutsatser och rekommendationer}

I detta avsnitt görs ett försök att samla ihop i punktform den del av resultaten samt de rekommendationer som framkom under workshopen och som anses vara mest aktuella för Småsamfundsgruppens framtidsplanering.

1. Småsamfundsgruppens arbete har största dels varit framgångsrikt. Detta gäller särskilt arbetet med Lokal Agenda 21 och avfallsfrågor. Den största framgången anses dock ligga i gruppens funktion som en plattform för utväxling av idéer och erfarenheter mellan de deltagande områdena.

2. Det som inte tycks ha lyckats lika bra är spridningen av det "goda budskapet”, såsom till lokalförvaltningar, branschorganisationer och enskilda företag.

3. Det finns utan tvekan behov för Småsamfundsgruppen i det framtida nordiska samarbetet. Det kommer nämligen alltid att finnas speciella uppgifter som inte kan lösas på samma sätt i småsamfund som i de stora samhällena.

4. Småsamfundsgruppen behöver ha tillräcklig flexibilitet för att löpande kunna ta tag i aktuella uppdrag i dagsläget.

5. Bland de mest aktuella områden är:

- Klimataspekter

- Miljögifter

- Fiskodling

- LA21-kontinuitet

- Avfall, bl.a.:

- Avfall från turism

- Rivningsavfall

- Organiskt avfall (småskala/lukt/transport)

- Avfall från notvaskerier (koppar m.m.)

- Möjligheter (idépark) för lokal avfallsbehandling

- Avlopp och avloppsrecipienter

- Miljöstyrningssystem och certifiering av dessa

- Grön inköp

- Hållbar konsumtion

- Industriell ekologi

6. Det föreslås att gruppen tar fram en utvärdering av de mest aktuella problemställningarna och sedan utarbetar en ny problembeskrivning.

7. Småsamfundsgruppen kunde löpande granska de aktiviteter som PAgruppens övriga undergrupper har på gång och identifiera vilka av dessa som behöver särskild tillpassning till småsamfund. Möjligen 
kunde detta även omfatta projekt och aktiviteter under övriga fasta arbetsgrupper under ÄK-M.

8. Småsamfundsgruppen bör ha en bättre hemsida som fungerar bl.a. som en upplysningstavla för gruppens olika projekt och aktiviteter. Alla relevanta institut i deltagarländerna/områden borde ha länkar till sidan på sina hemsidor.

9. Småsamfundsgruppen bör i ökad grad producera vägledning och information till företag och småkommuner om lösningar på aktuella problem, t.ex. gällande EU-direktiven.

10. Gruppens medlemmar bör ta på sig en större roll som "informationsspridningsagenter” på nationell nivå, bl.a. genom att informera om gruppens arbete i föredrag och annan kommunikation inför sina respektive forum.

11. Småsamfundsgruppen kunde organisera möten med representanter från kommuner för att skapa en översikt över aktuella problemställningar i småsamfunden samt för att sprida ut information om gruppens arbete.

12. Generellt skulle översättningar bidra till en bättre användning eller spridning av resultaten. I många fall kunde man få mer för pengarna genom att bevilja medel till översättningar i stället för till tryckning av rapporter.

13. Småsamfundsgruppen borde öppnas för nya regioner, men däremot borde man inte lägga för stor vikt vid att få dessa med, förutom kanske Grönland.

14. Potential för samarbete med små- eller ösamfund utanför Norden kan främst finnas i projektform, samt i form av informationsutväxling.

15. Småsamfund utgör en stor del, eller faktiskt den geografiska huvuddelen av Nordens territorium. Med utgångspunkt i detta är det särskilt viktigt att småsamfundens intressen och utmaningar avspeglas i Nordiska Ministerrådets strategier och handlingsprogram, samt i implementeringen av dessa. I samband med detta bör Småsamfundsgruppens medlemmar informera sina respektive miljöministrar om gruppens arbete.

16. Småsamfundsgruppens framgångsrika arbete med Lokal Agenda 21 bör fortfarande få plats i ett reviderat Miljöhandlingsprogram. I tillägg till detta bör bl.a. följande ingå i programmet:

- Ekoturism i småsamfund

- Avlopp - avloppsrecipienter - lokala lösningar

- Vattenvård, bl.a. m.h.t. Vattendirektivet (2000/60/EC)

17. Småsamfundsgruppen borde ta fram ett policydokument för att identifiera vilka aspekter som är viktiga i småsamfundssammanhang. Ett sådant dokument kunde vara ett nyttigt inspel till revideringen av den Nordiska strategin för hållbar utveckling, samt av Miljöhandlingsprogrammet. Småsamfundsgruppen bör vara proaktiv i sitt arbete i samband med revideringen. 


\section{Referenser}

Nordiska Ministerrådet. Miljøet i småog øsamfund i de nordiske lande. Projekter udført for Små- og øsamfundsgruppen under Nordisk Ministerråd, abstracts. Nordisk Ministerråd, København 1999.

http://www.norden.org/pub/sk/showp ub.asp?pubnr=2000:427 .

Nordiska Ministerrådet. Möjligheternas Norden - Nära dig. Finlands ordförandeskapsprogram för Nordiska Ministerrådet 2007. Nordiska Ministerrådet, ANP 2006:763, Köpenhamn 2006.

http://www.norden.org/pub/sk/showp ub.asp?pubnr=2006:763 .

Nordiska Ministerrådet. Nordic Action Programme on Cleaner Technologies, Waste and Recycling. Nordic Council of Ministers, NU 1990:004E, Copenhagen 1990. http://www.norden.org/pub/sk/showp ub.asp?pubnr=1990:004E .

Nordiska Ministerrådet. PA-gruppens hemsida:

http://www.norden.org/miljoe/pa/sk . Nordiska Ministerrådet. Småsamfundsgruppens hemsida: http://www.norden.org/miljoe/pa/sk/p a_smaasamfundsgrupp.asp .

Nordiska Ministerrådet. The Environment in Small and Island Communities in the Nordic Countries. Projects commissioned by The group for small and island communities under the Nordic Council of Ministers, Abstracts. Nordic Council of Minister, Copenhagen 1999. http://www.norden.org/pub/sk/showp ub.asp?pubnr=2000:428 . 



\section{Summary}

The group for small communities is the group within the Nordic Council of Ministers taking care of environmental and sustainability issues of particular importance for small communities in the Nordic Countries and the Arctic. The group's Terms of Reference expire at the end of 2008. During autumn 2007, the group carried out an evaluation of its work so far, in order to build a base for decisions on the future of the group after 2008. The central part of this evaluation was a workshop held in Hafnarfjordur, Iceland on 25-26 October 2007 with participants from the Nordic countries/regions that have been most actively involved in the work of the group, i.e. Iceland, the Faroe Islands, Åland Islands and Northern Norway. The North Calotte Council was represented at the workshop as well.

The main goal of the workshop was to provide answers to 7 different questions raised in a background paper, concerning the work of the group so far, as well as the need for the group in the years to come. The questions also addressed the optimal focus areas in the potential future work.

The work of the Nordic group for small communities has been successful in general, according to the workshop's results. This applies especially to the group's work on Local Agenda 21 and waste issues. The biggest success, however, is said to have been the way in which the group has managed to build a platform for exchange of information and ideas between the participating countries/regions. What is not seen as equally successful is the dissemination of "the good news", such as to local administrations, sector organisations and individual companies.

There is no doubt that the Nordic group for small communities is and will be needed, as there will always be some specific problems that cannot be solved in the same way in small communities as in the cities. But in order to be able to cope with the variety of tasks in a spontaneous way, the group needs certain flexibility.

Local Agenda 21 identifies waste issues in small communities and climate issues as two of the most important tasks of The Nordic group for small communities in the coming years. It is suggested that the group check, on a regular basis, the activities of the other groups within the environmental sector of The Nordic Council of Ministers, in order to identify which of these would need a specific adaptation for small communities. It is also suggested that the group identifies the most-pressing actual problem areas and creates a new description of these.

Dissemination of information was identified as the main weakness of the group. The homepage of the group should function better than it does now as a blackboard of different projects and activities. The members of the group should also play a bigger role as "dissemination agents" on the 
national level, such as by including information on the work of the group in presentations and other communication within their respective networks. In addition to this, the group could even organise meetings with representatives from municipalities to create an overview of urgent issues in small communities, as well as to spread information on the work of the group.

An increased emphasis on translations of the group's reports, etc. should, in general, lead to an improved use or dissemination of the results of the group's work, especially in Iceland and Finland. In many cases, money should even be invested in translations instead of being used for the publication of printed reports.

As the main part of the geographic area of the Nordic countries is composed of small communities, the interests and challenges facing these communities should be reflected in the strategies and action plans of The Nordic Council of Ministers, as well as in the implementation of these. The members of the Nordic group for small communities should, in this respect, inform their own environmental ministers on the work of the group.

The Nordic group for small communities should preferably create a policy document to identify the most important issues from small communities' point of view. Such a document could be a useful input to the revision of the Nordic Strategy for Sustainable Development, as well as the Nordic Environmental Action Plan. 


\section{Bilagor}

\section{Bilaga 1. Småsamfundsgruppens mandat}

Småsamfundsgruppen är en undergrupp under PA-gruppen (Produkt och avfall) under Nordisk Ministerråd, ÄK-Miljö.

\section{Syfte}

Gruppens syfte är att bidra till uppföljningen av den Nordiska Hållbarhetsstrategin och det Nordiska Miljöhandlingsprogrammet 2005-2008, särskilt deltema 4.1, "Renere produkter og affald", härunder at styrke og udvide aktiviteter omkring Lokal Agenda 21, miljøledelse og bedste tilgængelige teknologi i småsamfund i Norden.

\section{Gruppen skall}

1. Fortsätta stärka och utvida arbetet med Lokal Agenda 21 och miljöstyrning i Norden med speciell fokus på småsamfund och arktiska problemställningar

2. Främja miljömässiga arbetsmetoder i småsamfund, härunder kring förebyggande och behandling av avfall, med speciell fokus på hållbar produktion och konsumtion samt övergången till konkreta handlingar för att främja en hållbar utveckling.

3. Uppmana kommuner att utveckla nätverk och sprida erfarenhet och goda exempel kring hållbar utveckling.

4. Arbeta för att utveckla och synliggöra goda, nordiska exempel på hållbar produktion och söka integrera miljökunskap i alla sektorer, främst i småsamfund.

5. Bidra till ett förbättrat samarbete mellan företag och offentliga myndigheter, samt mellan myndigheter och medborgarsamhället, främst i småsamfund.

6. Främja spridning av information mellan nordiska experter och/eller myndigheter för att understötta PA-gruppens verksamhet, främst i småsamfund.

\section{Projekt teman}

1. Bedre miljøkundskab i befolkningen og i virksomhederne

2. Folkens deltagelse og lokal Agenda 21

3. Miljöstyrning

4. Miljöhandlingsplaner i kommuner 
5. Avfall i hamnar och avfallshandlingsplan för hamnar

6. Insamling och behandling av farligt avfall från små skeppsvarv

7. Avlopp och avloppsmottagare

8. Utsläpp från industrier

9. Arktiske miljøgifter

10.Fiskodling

11.Turismens miljöproblem

Arbetsform

1. Gruppen sammanträder 1 till 3 gånger per år.

2. Gruppen kan genomföra projekt, arrangera temamöten och seminarier i överenstämmelse med PA-gruppens arbetsprogram och budget. I så fall fungerar gruppen som styringsgrupp för projekten.

3. Gruppen utför en årlig prioritering av aktiviteter.

\section{Informationsverksamhet}

Gruppens arbete rapporteras till PA-gruppen genom referat från gruppens möten, samt statusrapporter och orientering under PA-gruppens möten. Gruppen skal se till att information om gruppens arbete sprids till relevanta målgrupper. När projekt igångsätts skal det fokuseras på: Varför är det intressant? Vad är budskapena? Vem är målgruppen? Hur sprids budskapena?

Detta mandat gäller för perioden 15 september 2005 til 31 december 2008, med möjlighet för en årlig revidering.

Vidtagit av PA-gruppen 9 sept 2005

\section{Bilaga 2. PA-gruppens mandat}

1. EK-Ms nationale delegationer udpeger for hvert af de nordiske lande sagkyndige medlemmer til den nordiske produkt- og affaldsgruppe. De selvstyrende områder kan udpege medlemmer til gruppen. Medlemmerne skal i gruppen kunne repræsentere nationale synspunkter samt kunne sikre national forankring, implementering og formidling af gruppens arbejde. Medlemmerne skal besidde faglig viden indenfor gruppens mandatområde.

2. I det nordiske miljøhandlingsprogram 2005-2008 har MR-M fastlagt retningslinierne for gruppens arbejde. De af ministerrådet fastlagte retningslinier for projektvirksomheden skal lægges til grund for gruppens virksomhed, særligt tema IV: Bæredygtig produktion og konsumption, herunder delmål 4.2 om renere produkter og affald. 
3. Gruppen skal fremme en udvikling som bygger på bæredygtig produktion og konsumption. Hertil kommer nordiske indspil til forebyggelse af mængden og miljøfarligheden af affald, øget genanvendelse af affald, bedre miljøkundskab i befolkningen og i virksomhederne, bedre produktinformation samt fremme af grønne markeder og bæredygtig og renere teknologi. Gruppen skal arbejde for at forebygge og mindske produktionens og konsumptionens negative påvirkning af miljøet samt bidrage til effektiv anvendelse af naturressourcerne i hele deres livscyklus.

Gruppen skal fremlægge forslag for EK-M om konkrete, begrundede initiativer indenfor sit fokusområde, også med udgangspunkt i relevante mål i den nordiske strategi for bæredygtig udvikling 20052008, særligt under område 2: Bæredygtige produktions- og forbrugsmønstre og område 15: Allmänhetens deltagande och lokala Agenda 21. Gruppen skal ligeledes tage initiativ overfor Nordens nærområder med særlig hensyn til at støtte kompetenceopbygning og bidrage til aktiviteter i disse områder.

Gruppen skal følge op på internationale initiativer af relevans for gruppens arbejdsområde. Gruppen skal koordinere den nordiske indsats i forhold til EU/EØS, UNEP og andre internationale organisationers programmer om ressourceeffektivitet, produkter og affald. I forhold til EU/EØS skal gruppen særlig fokusere på koordinering af nordiske indsats til direktiver og strategier som er under udarbejdelse og integrerer udvikling af renere produkter og affaldsbehandling, bl.a. direktiverne om batterier, slam og bionedbrydeligt affald samt EU's genanvendelsesstrategi. Gruppen nedsætter projekt- og netværksgrupper for at fremme formidling af information mellem nordiske eksperter og/eller myndigheder og for at understøtte gruppens virksomhed.

4. Gruppen skal koordinere og tage initiativ til samarbejde med berørte arbejdsgrupper under EK-M og andre sektorer under Nordisk Ministerråd, på sagsområder som falder ind under gruppens virksomhedsområde. Gruppen skal tage initiativ til samarbejde og indsatser for at følge op på det nordiske miljøhandlingsprogram 2005-2008, strategien for en bæredygtig udvikling 2005-2008 samt det gældende formandskabsprogram.

5. Gruppen skal være ansvarlig for at formidle bredt og aktivt allerede fra begyndelsen af miljøhandlingsprogrammperioden. Hver gang et projekt sættes i gang skal der fokuseres på: Hvorfor er det interessant? Hvad er budskaberne? Hvem er målgruppen? Hvordan formidles bud-skaberne?

6. Gruppen skal årligt levere en virksomhedsberetning inklusiv regnskab i overensstemmelse med den fastlagte model.

Gruppen skal årligt udarbejde et forslag til arbejdsprogram og budget for dens virksomhed i overensstemmelse med den fastlagte model. På 
basis af dette forslag som godkendes af EK-M/MR-M kan gruppen søge om medler over Nordisk Ministerråds budget til projekt- og udredningsvirksomhed. Der kan endvidere søges om midler nationalt og internationalt.

7. EK-M træffer på baggrund af anbefaling fra gruppen beslutning om placering af formandskab og sekretariat. Formand og sekretær skal ikke nødvendigvis følge hinanden.

Sekretæren skal være tilknyttet en institution/organisation i Norden, som har sagkyndig kompetence og kapacitet til administrativ samt budget- og regnskabsmæssig opfølgning.

Formandskab vælges for ét år af gangen i overensstemmelse med NMRS retningslinier med mulighed for forlængelse, max 3 år.

Sekretæren vælges for to år af gangen med mulighed for forlængelse, max 4 år. Der bør tilstræbes, at formand og sekretær ikke skiftes samtidig.

8. Dette mandat gælder for perioden 1. januar 2005 til 31. december 2008

9. Gruppen skal i løbet af 2008 fremkomme med grundlag til EK-M’s stillingtagen til et fortsat arbejde. Dette grundlag bør omfatte elementer for opdatering af miljøhandlingsprogrammet Godkendt desember 2004 